\title{
Ecological mechanisms underlying aridity thresholds in global drylands
}

\author{
Miguel Berdugo, ${ }^{1,2,3, *}$ Blai Vidiella, ${ }^{1,2}$ Ricard V. Solé, ${ }^{1,2,4}$ and Fernando T. Maestre ${ }^{5,6}$ \\ ${ }^{1}$ ICREA-Complex Systems Lab, UPF-PRBB, Dr. Aiguader 80, 08003 Barcelona, Spain \\ ${ }^{2}$ Institut de Biologia Evolutiva, CSIC-UPF, Passeig Maritim de la Barceloneta 37, 08003 Barcelona, Spain \\ ${ }^{3}$ Institute of Integrative Biology, Department of Environment Systems Science, ETH Zürich, 8092 Zürich, Switzerland \\ ${ }^{4}$ Santa Fe Institute, 1399 Hyde Park Road, Santa Fe NM 87501, USA \\ ${ }^{5}$ Instituto Multidisciplinar para el Estudio del Medio "Ramon Margalef", Universidad de Alicante, \\ Carretera de San Vicente del Raspeig s/n, 03690 San Vicente del Raspeig, Alicante \\ ${ }^{6}$ Departamento de Ecología, Universidad de Alicante, \\ Carretera de San Vicente del Raspeig s/n, 03690 San Vicente del Raspeig, Alicante, Spain
}

1. With ongoing climate change, the probability of crossing environmental thresholds promoting abrupt changes in ecosystem structure and functioning is higher than ever. In drylands (sites where it rains less than $60 \%$ of what is evaporated), recent research has shown how the crossing of three particular aridity thresholds (defining three consecutive phases, namely vegetation decline, soil disruption and systemic breakdown) leads to abrupt changes on ecosystem structural and functional attributes. Despite the importance of these findings and their implications to develop effective monitoring and adaptation actions to combat climate change, we lack a proper understanding of the mechanisms unleashing these abrupt shifts.

2. Here we revise and discuss multiple mechanisms that may explain the existence of aridity thresholds observed across global drylands, and discuss the potential amplification mechanisms that may underpin hypothetical abrupt temporal shifts with climate change.

3. We found that each aridity threshold is likely involving specific processes. In the vegetation decline phase we review mainly physiological mechanisms of plant adaptation to water shortages as main cause of this threshold. In the second threshold we identified three pathways involving mechanisms that propagates changes from plants to soil leading to a soil disruption: erosive mechanisms, mechanisms linked to an aridity-induced shrub encroachment and mechanisms linked to nutrient cycling and circulation. Finally, in the systemic breakdown phase we reviewed plant-plant amplification mechanisms triggered by survival limits of plants that may cause sudden diversity losses and plant-atmospheric feedbacks that may link vegetation collapse with further and critical aridification.

4. By identifying, revising and linking relevant mechanisms to each aridity threshold, we catalogued a set of specific hypotheses and recommendations based on identified knowledge gaps concerning the study of mechanisms of threshold emergence in drylands. Moreover, we were able to establish plausible factors that are context dependent and may influence the occurrence of abrupt changes in time and we created a mechanistic-based conceptual model on how abrupt changes may emerge as aridity increases. This has importance for focusing future research efforts on aridity thresholds and for developing strategies to track, adapt to or even revert these abrupt ecosystem changes in the future.

\section{INTRODUCTION}

Ongoing climate change is producing changes in key ecosystem attributes and functions that are affecting human populations worldwide (Stocker et al. 2013). Of particular concern is the fact that climate warming may entail crossing critical planetary boundaries (certain levels of environmental attributes, e.g., temperature or precipitation, Rockström et al. 2009) that, when crossed, may increase the risk of generating large-scale abrupt or irreversible changes (Scheffer and Carpenter 2003; Scheffer et al. 2015; van Nes et al. 2016). These boundaries are relevant for ecosystem management and underpin a significant part of the political frameworks used nowadays to understand and face the threats imposed by climate change (Rockström et al. 2009; Steffen et al. 2015). In this context, identifying environmental thresholds ("the point in which there is an abrupt change in an ecosystem quality, property or phenomenon, or where small changes in an environmental driver produce large responses on the ecosystem", Groffman et al. 2006) has become of the utmost importance to quantify tangible

*Corresponding author: M. Berdugo (mglberdugo@gmail.com) targets defining "safe operational space" of ecosystem services (Allen 2009). Thresholds in ecosystem structural and functional attributes have two main facets that makes them important. First, changes in ecosystems when surpassing a threshold are abrupt, producing sudden transformation of ecosystems that may affect the livelihood of people that rely on ecosystem services for their survival (Suding and Hobbs 2009; Botta et al. 2019). Second, abrupt changes resulting from crossing thresholds may suppose the change into an alternative stable state of the system, making this change hardly reversible once it happens (Scheffer et al. 2001; Morris 2011; van Nes et al. 2016). This second facet of thresholds is associated to a particular phenomenon called catastrophic shift which so far has been studied mainly using theoretical models (May 1976; Scheffer et al. 2001; Filatova et al. 2016). It is important to note that experiencing abrupt transformations do not necessarily entail the existence of stable states and thus these two facets of thresholds are not always connected. Empirical studies conducted along spatial gradients have provided some good examples of nonlinear patterns of ecosystem attributes using environmental gradients in arctic (Scheffer et al. 2012), tropical (Hirota et al. 2011; Verbesselt et al. 2016; Xu et al. 2016) and dryland (Wang et al. 2014; Luo et al. 2016; Berdugo et al. 2017, 2020) 
ecosystems. Such approaches evidence the existence of particular environmental thresholds affecting important biotic attributes of ecosystems (e.g., plant cover, tree cover, soil carbon or soil microbial communities). Thresholds are, however, more difficult to find when manipulative experimentation is used (Hillebrand et al. 2020). This discrepancy between observational and experimental results is partly underpinned by the lack of a mechanistic understanding we have on how thresholds in ecosystems emerge (Kreyling et al. 2014). Indeed, neither the use of mathematical models nor threshold quantification using spatial gradients is a good approach for understanding the mechanisms that trigger abrupt responses of ecosystems, either because the examination of general patterns present strong limitations to infer such mechanisms (McIntire \& Fajardo 2009; Damgaard 2019) or because models simplify assumptions on ecosystem functioning to be operational (Schaffer 1981). Nevertheless, understanding the mechanisms by which a given ecosystem respond abruptly to environmental changes is key to better focus potential management of ecosystems aiming at preventing or even reverting such abrupt responses (Suding et al. 2004; Suding \& Hobbs 2009; Kreyling et al. 2014; Villa Martín et al. 2015). Besides, envisioning mechanisms of threshold occurrence may reveal the existence of intrinsic ecosystem factors (such as existing soil microbial or plant community) or other global change drivers (such as changes in land use intensity or nitrogen deposition) that may make the occurrence of thresholds context-dependent. Furthermore, understanding these confounding factors is key to translate our knowledge of threshold occurrence from spatial gradients into temporal changes. There are two broad types of mechanisms that may explain the abrupt nature of the change produced by thresholds. First, some abrupt changes are easily explained by the nonlinear behaviour of the ecosystem attribute that is affected (Andersen et al. 2009). For instance, physiological thresholds in organisms for surviving or recruiting (Ficetola \& Denoël 2009; Choat et al. 2018) trigger an abrupt natural response (e.g., death or dormancy) that is nonlinear and that does not requires additional mechanisms to be explained. In other cases, abrupt shifts depend on the amplification of the ecosystem response through the interactions between different ecosystem features. This introduces the concept of positive feedback, which is defined as "an interaction in which a perturbation in one component of the system causes a change in a second and the change in the second ultimately leads to an additional change in the first" (Stocker et al. 2013). These feedbacks reinforce changes triggered by environmental changes amplifying the response of the system and unleashing abrupt shifts. Soils and plants, but also plants and atmospheric drivers often exhibit positive feedbacks in their interaction (e.g., soil erosion and vegetation cover, (Schlesinger et al. 1990; D'Odorico et al. 2012)). Identifying the component of the feedback that is actioned by a particular environmental change or disturbance, thus triggering the loop, and the relevant secondary components that accelerate the response and make it abrupt is key to un- derstand, manage or even revert threshold behaviours (Suding et al. 2004; Villa Martín et al. 2015). It is important to mention that systems exhibiting positive feedbacks usually (but not always, (Andersen et al. 2009)) are strong candidates of exhibiting alternative stable states (Holling 1973; May 1976; Scheffer et al. 2001). Herein we review the mechanisms unleashing environmental thresholds using global drylands as a relevant study case. In these areas, thresholds have long been hypothesized by theoretical approaches (Kéfi et al. 2007b; D'Odorico et al. 2012; $\mathrm{Xu}$ et al. 2015a) and are being empirically evidenced using space for time substitution approaches (Wang et al. 2014; Berdugo et al. 2020). By doing so, we aim at shedding light into potential mechanisms that unleash environmental thresholds in global drylands and exemplify a more general working flow that may be applied to other ecosystems.

\section{A. THE CASE OF STUDY: DRYLANDS}

Drylands, defined as areas with an aridity index (AI, ratio between precipitation and potential evapotranspiration) below 0.65 (Middleton \& Thomas 1992), collectively form the largest biome of Earth ( $41 \%$ of terrestrial surface (Cherlet et al. 2018)). Aridity (referred throughout this review as $1-A I$ ), is a major driver of ecosystem structure and functioning across drylands worldwide (Noy-Meir 1973; Maestre et al. 2016; Berdugo et al. 2020). Therefore, ongoing (Prăvălie et al. 2019) and forecasted (Huang et al. 2015, 2017; Cook et al. 2020; Yao et al. 2020) increases in aridity driven by climate change may have important impacts on the structure and functioning of drylands, and thus on their capacity to provide essential ecosystem services for the more than 2 billion people inhabiting them (Middleton et al. 2011; Cherlet et al. 2018). Of particular relevance is the fact that changes imposed by increasing aridity may not necessarily occur gradually (Schlesinger et al. 1990; Scheffer et al. 2001; Berdugo et al. 2020). Recent research evaluating how drylands change along the wide aridity gradient that can be found worldwide (environmental gradients) shows three major nonlinear shifts in multiple ecosystem attributes associated to several aridity thresholds (Wang et al. 2014; Hou et al. 2019; Berdugo et al. 2020). At aridity values of 0.54 there is a shift in photosynthesis efficiency that, when observed using remote sensing data at ecosystem scales, marks a segmented pattern decreasing the negative slope of Normalized Difference Vegetation Index (NDVI) with aridity (Berdugo et al. 2020). When observed at the plant individual level, the photosynthetic capacity shifts from a positive correlation with aridity to a negative one around same aridity value (Berdugo et al. 2020). This marks the vegetation decline phase. Nonlinear changes in nutrient pools associated to increasing aridity where first showed by (Delgado-Baquerizo et al. 2013b), and a threshold of aridity 0.7 was first suggested by (Wang et al. 2014) when seeing an abrupt decrease in nitrogen transformation rates of sites with a climate beyond this aridity 


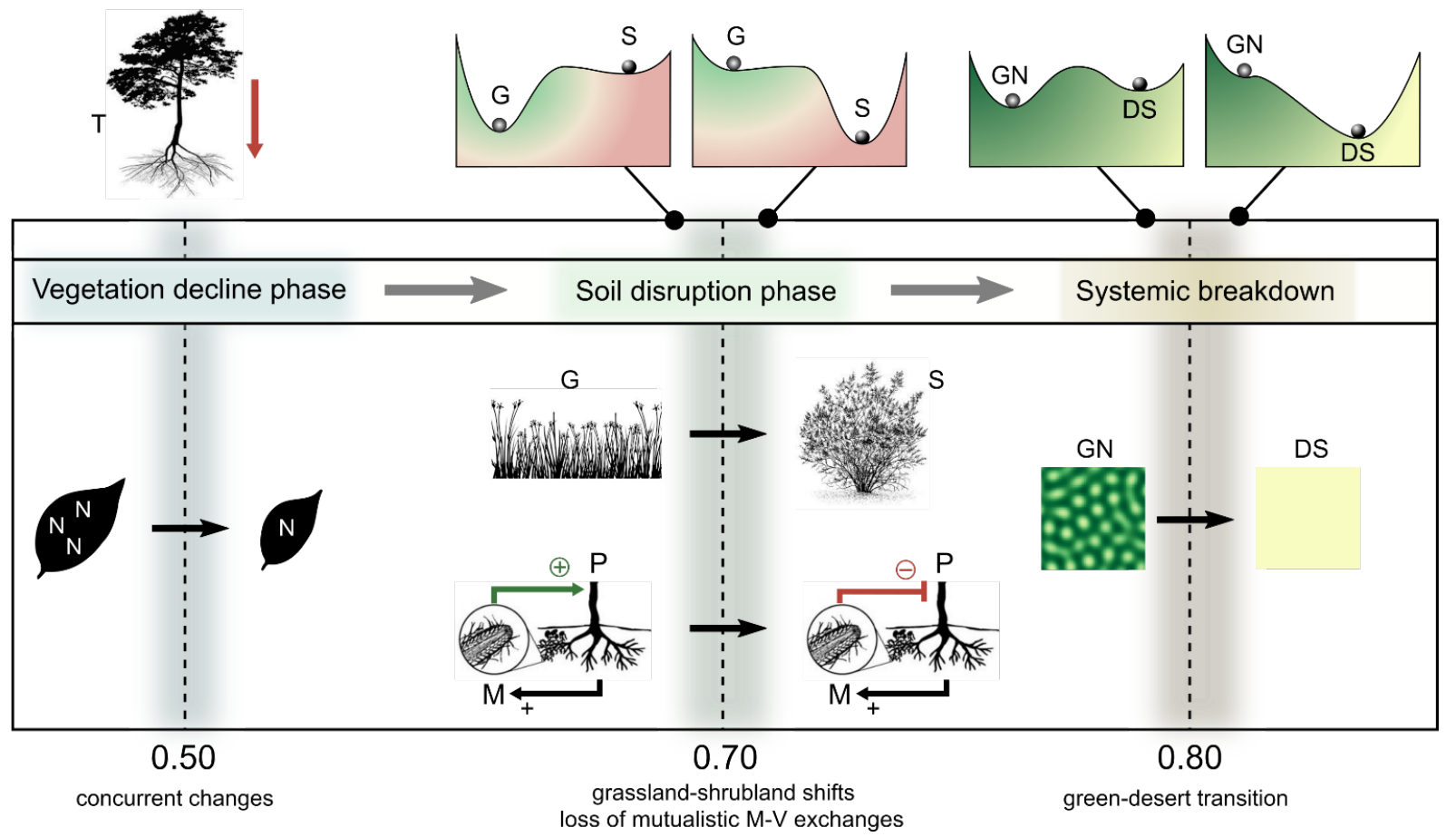

FIG. 1: Conceptual model on the nature of shifts in drylands when critical levels of aridity are achieved. In this diagram (adapted from figure 1 in Berdugo et al. 2020) we can see how observable changes in aridity can correlate with predicted shifts (gray areas) from nonlinear models. The first change (vegetation decline phase) does not match any specific sudden transition scheme. Instead, several concurrent changes seem to take place close to 0.5 aridity levels related with physiological adaptation to water stress. By contrast, the other two shifts have been described by mathematical models involving sudden transitions leading to new ecological states. For the 0.7 point, the best known is the grassland (G)-shrub (S) transition. For this model (see for example d'Odorico et al, 2011) we can visualize this flip using the landscape $\mathrm{V}(\mathrm{x})$ depicted in the upper part where the possible states (here $\mathrm{G}$ and $\mathrm{S}$ ) are the minima for each aridity condition. In general, this change in alternative stable states are related with soil-vegetation positive feedbacks (e.g., through mycorrhizal; M). Similarly, the systemic breakdown phase has been extensively studied from the perspective of so called green-desert (GN-DS) transitions where a catastrophic change separates a vegetated (and patterned) state to bare soil. We hypothesized that this final transition is the result of plant-plant and plant-atmospheric feedbacks concurring with exceeding physiological limits of the most well adapted perennial vegetation.

value. Later confirmation of the abruptness of these responses on soil fertility (Berdugo et al. 2017) and soil micronutrients (Luo et al. 2016) pointed to abrupt changes in soil properties around this aridity value. However, more ecosystem features and functions have been found to change abruptly or non-linearly at this threshold, including: a) microbial communities (Delgado-Baquerizo et al. 2020), b) mycorrhizal relative abundance, c) fungi abundance, d) plant amelioration of soils, e) development of shrublands (Berdugo et al. 2020), f) plant-plant interactions (Berdugo et al. 2018) and spatial patterns (Berdugo et al. 2017, 2019) and g) nitrogen in leaves at plant individual level (Berdugo et al., 2020). This is the soil disruption phase. Finally, abrupt declines in perennial vegetation cover and in perennial plant species richness, are reported at aridity levels around 0.82 (Berdugo et al. 2020). These aridity values match those found in other studies showing drastic turnover in dryland flora (Ulrich et al. 2014) and a shift in leaf strategies to cope with aridity stress from stress tolerance to stress avoidance (Carvajal et al. 2018; Berdugo et al. 2020). This is the systemic breakdown phase. Such a concurring evidence from independent studies highlights the existence of systemic (i.e., attaining several ecosystem compartments), sequential (as aridity increases) and global ecosystem thresholds associated with increases in aridity across drylands worldwide. According to aridity forecasts (Huang et al. 2015), up to $22 \%$ of emerged lands may cross one or several of these aridity thresholds by the end of this century (Berdugo et al. 2020). Using the general framework explained above of three consecutive nonlinear changes of dryland ecosystem attributes with increasing aridity, here we review the plausible mechanisms associated to each phase as well as their interconnection to create a more general set of hypotheses regarding mechanisms of threshold emergence. By doing so we catalogued a set of recommendations for future studies, we were able to establish plausible factors that are context dependent and may influence the occurrence of abrupt changes in time and we created a mechanistic-based conceptual model on how abrupt changes may emerge as aridity increases. We elaborated this conceptual model in figure 1, where some of the mechanisms are put as examples of the abrupt shifts depicted per phase. Mechanisms are dissected individually phase by phase in the next sections and are summarized in table I . 
TABLE I: Summary of mechanisms explored for aridity thresholds with triggers and key processes involved in each. Possibility of exhibiting hysteresis, and thus catastrophic shift is documented as well as relative expected rates of dynamical change, secondary factors to be studied in each mechanism and the action capacity for hypothetical restoration or prevention of each mechanism.

\begin{tabular}{|c|c|c|c|c|c|}
\hline Threshold & Mechanism & Triggers & Key process & $\begin{array}{l}\text { Alternative } \\
\text { states } \\
\text { emerging }\end{array}$ & $\begin{array}{l}\text { Secondary } \\
\text { factors }\end{array}$ \\
\hline $\begin{array}{c}\text { Vegetation } \\
\text { decline phase }\end{array}$ & $\begin{array}{l}\text { Photosynthetic } \\
\text { physiological }\end{array}$ & $\begin{array}{l}\text { - Water becomes limiting in } \\
\text { photosynthesis }\end{array}$ & $\begin{array}{l}\text { Plant drought } \\
\text { resistance }\end{array}$ & Unlikely & $\begin{array}{ll}- & \mathrm{CO} 2 \\
& \text { fetilization } \\
- & \text { Vegetation } \\
& \text { history }\end{array}$ \\
\hline \multirow{3}{*}{$\begin{array}{c}\text { Soil } \\
\text { disruption } \\
\text { phase }\end{array}$} & Erosive pathway & $\begin{array}{l}\text { - Vegetation reduction } \\
\text { - Wind-water erosion } \\
\text { importance }\end{array}$ & $\begin{array}{l}\text { Soil physical } \\
\text { erosion }\end{array}$ & Likely & $\begin{array}{ll}\text { - Extreme } \\
\text { events } \\
\text { - } \\
\text { Topography, } \\
\text { soil }\end{array}$ \\
\hline & $\begin{array}{l}\text { Shrub } \\
\text { encroachment } \\
\text { pathway }\end{array}$ & $\begin{array}{l}\text { - Change in aboveground } \\
\text { community }\end{array}$ & $\begin{array}{l}\text { Shrub } \\
\text { recruitment }\end{array}$ & Likely & - Grazing \\
\hline & $\begin{array}{l}\text { Biogeochemical } \\
\text { pathway }\end{array}$ & $\begin{array}{l}\text { - Shift in belowground } \\
\text { community } \\
\text { - Drastic decrease in } \\
\text { decomposition rates }\end{array}$ & $\begin{array}{l}\text { Nutrient } \\
\text { cycling }\end{array}$ & Unexplored & - Soil legacy \\
\hline \multirow{3}{*}{$\begin{array}{c}\text { Systemic } \\
\text { breakdown } \\
\text { phase }\end{array}$} & $\begin{array}{l}\text { Physiological } \\
\text { collapse }\end{array}$ & $\begin{array}{l}\text { Soil water potential bellow } \\
\text { wilting point }\end{array}$ & $\begin{array}{l}\text { Plant } \\
\text { physiological } \\
\text { limits }\end{array}$ & Unlikely & $\begin{array}{l}\text { - Vegatation } \\
\text { adaptation. } \\
\text { - } \text { Biocrusts }\end{array}$ \\
\hline & BEF feedback & $\begin{array}{l}\text { - Cascading collapse } \\
\text { through interaction } \\
\text { networks } \\
\text { - Species richness bellow a } \\
\text { critical value }\end{array}$ & $\mathrm{BEF}$ & Unexplored & $\begin{array}{l}\text { - Vegetation } \\
\text { history }\end{array}$ \\
\hline & Plant-atmosphere & - Reductions in plant cover & $\begin{array}{l}\text { Rainfall } \\
\text { formation }\end{array}$ & Likely & $\begin{array}{ll}\text { - Evapotransp } \\
\text { iration } \\
\text { - Albedo. }\end{array}$ \\
\hline
\end{tabular}

\section{MECHANISMS LINKED TO THE VEGETATION DECLINE PHASE}

In the vegetation decline phase, observed changes in the slope of productivity with increasing aridity suggest a mechanism of adaptation to lack of water or a replacement in the drivers of productivity from temperature to rainfall at these aridity values. Both are probably physiological shifts, meaning that the adaptation of plants to an increasing water scarcity is the trigger of this nonlinear change. Indeed some studies already evidenced that dry-subhumid ecosystems, whose change into semiarid occur around aridity of 0.6 , are less influenced by water and more by temperature (Nemani et al. 2003). Other studies showed also increasing control of soil moisture on chlorophyll fluorescence after aridity values of 0.5 (Liu et al. 2020). Water availability is not only reduced as aridity increases, but also becomes more variable and unpredictable (Le Houérou 2001). Thus plants must deal with both seasonal water shortages and more frequent droughts (Schlaepfer et al. 2017) forcing them to be active only when "pulses" of water become available (Noy-Meir 1973; Collins et al. 2014; Feldman et al. 2018). Several studies have reported concurring evolutionary adaptations in dryland plants that allow them to tolerate water shortages (Schwinning and Ehleringer 2001; Bussotti et al. 2014). These include production of smaller and thicker leaves that prevent water evaporation through stomatal closure in unfavourable conditions (Quiroga et al. 2010), ultimately reducing the costs of mechanisms to endure water shortages (Mansfield and Freer-Smith 1984; Reich 2014; Nunes et al. 2017). These adaptations either restrict the normal functioning of photosynthesis or allow the functioning in a less efficient manner under water stress (Mansfield and Freer-Smith 1984). This implies a reduction of both plant and ecosystem level photosynthetic capacity but allows plants to thrive and survive under unfavourable periods, thus increasing the overall ability of the ecosystem to maintain its functioning under aridity stress (Schwinning and Ehleringer 2001). Our hypothesis is that vegetation decline phase starts when such water shortage adaptations become of high relevance forcing plants to change their leaf traits and producing a community turnover. To corroborate this, studying plant leaf changes at both sides of this threshold is key. This is difficult because dry-subhumid ecosystems encompass wide range of ecosystem typologies (from cold to hot environments, taiga, forests and grasslands) and responses of ecosystems may be different depending on 
ecosystem subtypes studied. Indeed, previous studies on plant physiology across environmental gradients in drylands do not show an aridity gradient wide enough or did not encompass a wide range of ecosystem typologies of dry-subhumid drylands, thus our knowledge regarding this community turnover is still hampered by lack of comprehensive studies of plant physiology at global scales. If changes in vegetation physiology to accommodate water shortages are the main mechanism underpinning the existence of vegetation decline phase, this has two important consequences to understand how dryland ecosystems may suffer this threshold in time. First, because plant physiological adaptation to water stress was achieved through evolutionary scales, it is unlikely that plants in sites undergoing the vegetation decline phase will adapt to the new aridity conditions to prevent degradation at timescales of climate change (years-decades, Stocker et al. 2013). Thus, vegetation decline phase may be conditioned to ecosystem history and the existing vegetation community living in these areas. On this regard, processes such as plant acclimation (Bussotti et al. 2014; Wang et al. 2020), the immigration of plants that are well-adapted to water limitation from more arid places and a turn-over of the plant community to adapt to the new conditions (Neilson et al. 2005) are key confounding factors that need to be the focus of future studies aiming at understanding the possible occurrence of vegetation decline phase in time. Second, some studies have already related increases in atmospheric CO2 (associated with climate change) with increasing water use efficiency for photosynthesis and observed vegetation greening in drylands ( $\mathrm{Lu}$ et al. 2016). This "fertilization effect" of CO2 may partly counteract the decline in photosynthesis due to increasing aridity. However, it may not suffice to relief the effect of increasing dryness, as seen in some recent studies (Bussotti et al. 2014; Brookshire and Weaver 2015; Peñuelas et al. 2017; He et al. 2019). Indeed, whether there is a critical aridity value where CO2 fertilization effects on photosynthesis lessen respect to water shortages is yet to be elucidated. On the other hand, recent studies indicate that increasing evaporative demand by plants is linked to temperature regulation in extremely hot environments (Aparecido et al. 2020), thus it is likely that climate warming itself may exacerbate water use in plants, counteracting CO2 fertilization.

\section{MECHANISMS LINKED TO SOIL DISRUPTION PHASE}

Mechanisms behind the soil disruption phase should explain why soil structure and biogeochemical cycles are suddenly disrupted at aridity values 0.7 and why plant dominant growth form switch from forests or grasslands to shrublands. Besides, these mechanisms need to take into account the inherited declining photosynthesis from the vegetation decline phase. Drylands are paradigmatic examples of very complex plant-soil feedbacks underpinning their functioning (Ehrenfeld et al. 2005; D'Odorico et al. 2007) and giving birth to their well-known heterogeneity. Our hypothesis is that abrupt changes depicted in soil disruption phase are the result of this complex interaction between soils and plants. By doing an in-depth revision of the literature, we find three main pathways for these feedbacks to occur (see figure 2) and, probably, several of them act in tandem in response to increasing aridity.

\section{A. The erosive pathway}

The main hypothesis underpinning this pathway is that aridity modifies soil physical structure (e.g., producing changes in soil texture Delgado-Baquerizo et al. 2013b; Wendling et al. 2019) by mediating in soil erosive processes and that this change propagates to other ecosystem features. In this line, there are two mechanisms linking soil erosion with aridity. The first mechanisms is related to the interaction between soil erosion and vegetation, the so-called plant-soil erosion feedback (Schlesinger et al. 1990). This mechanism builds on the next rationale: if plants reduce their cover, soils become vulnerable to erosion and this reinforce further reductions in plant cover. This plantsoil erosion feedback is often adopted in theoretical studies (Kéfi et al. 2007a) and it is highlighted as a possible way towards desertification producing alternative stable states (Schlesinger et al. 1990; Wendling et al. 2019). The trigger of this feedback (a reduction in vegetation cover) is indeed observed at this aridity level (0.7) across global drylands (Berdugo et al., 2020), probably because of continuous decreasing of photosynthetic activity inherited from the previous phase. This reduction in cover, even if occurring smoothly, may trigger abrupt soil losses. For instance, at cover values of $60 \%$ clumps of vegetation are less likely to occur by chance, exposing more soil surface to erosive drivers (Abades et al. 2014). Indeed, other studies suggest the existence of thresholds on the erodibility of soils associated to certain insufficient plant cover which may imply an acceleration of erosion (Mora and Lázaro 2013). Some classical studies spot this threshold in vegetation cover to be around $30 \%$ (Elwell \& Stocking 1976; Francis \& Thornes 1990). Another possible mechanism is a change in the relative importance of erosive agents driven by aridity. It has been suggested that aeolian erosion increases respect to water-driven erosion as water becomes more limiting (Ravi et al. 2007), hypothesizing an aridity level in which aeolian erosion becomes more prevalent than water erosion (Ravi et al. 2007). Although this threshold has not been identified yet, it is hypothesized to occur in arid and hyperarid regions (Ravi et al. 2010), thus matching aridity levels of the soil disruption phase. The identity of soil erosive drivers determines both the total amount of erosion (Breshears et al. 2003; Xu et al. 2015b) and the spectrum of particle sizes that are eroded (Gillette et al. 1974; Zamani \& Mahmoodabadi 2013). Indeed, strong dependence on soil particle size in wind erosion (Stout 2007) may imply a bias towards fine particles in wind-driven erosion that, with time, may change the soil textural 


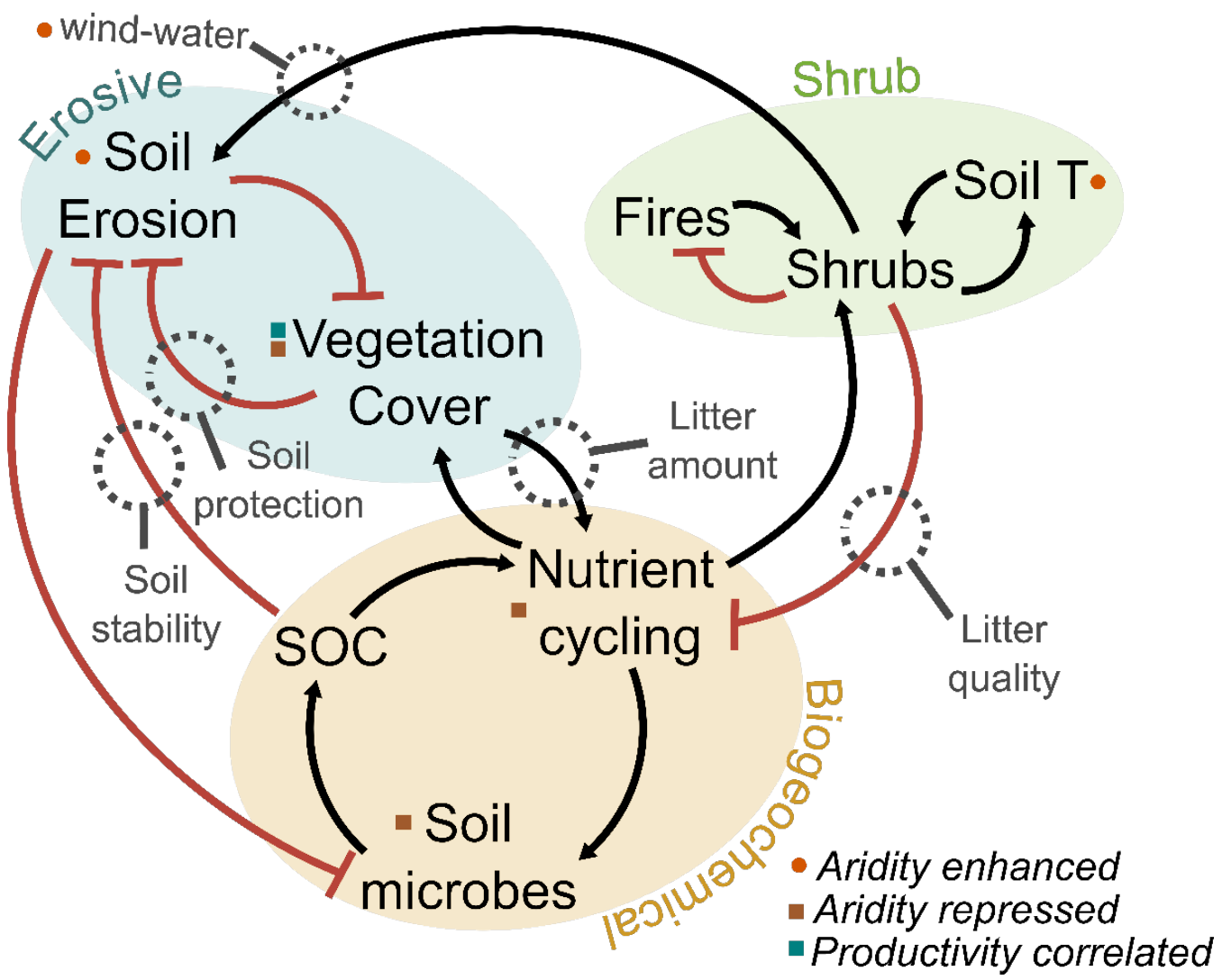

FIG. 2: Feedbacks hypothetically involved in soil disruption phase and grouped in three potential pathways involving soil erosion (red), shrub encroachment (green) and biogeochemical pathways (yellow). Red arrows indicate the negative correlation between processes (i.e. increases in aridity induce reduction of rainfall), while black arrows indicate a positive one (i.e. increase in rainfall increases the vegetation cover). Blue square means that the property is affected by the previous transition.

properties (Li et al. 2009; Colazo \& Buschiazzo 2015). In addition, this exchange of erosive drivers has important consequences on the formation of vegetation spatial arrangements (Ravi et al. 2008) and is modulated by plant cover (Munson et al. 2011) and plant life form (Breshears et al. 2003). Thus, this mechanism might not be unrelated from plant-soil erosion feedbacks. Either if initialized or exacerbated by vegetation reductions or by changes in erosive drivers, soil erosion would easily affect other ecological features than plants or soil texture. For instance, soil texture affects directly (Bach et al. 2010) and indirectly (by affecting soil carbon contents, Xiaojun et al. 2013; Fierer 2017) the soil microbiome. Indeed, erosion is a major soil carbon depletion mechanism (Naipal et al. 2018; Lal 2019), being wind erosion an important, but usually overlooked, driver of soil carbon losses in drylands (Chappell et al. 2019). Besides, in coarse textured soils water would infiltrate at higher rates and become available mostly at deep layers (Mavimbela \& van Rensburg 2017), thus emerging as a filter selecting for plants with deep roots (Noy-Meir 1973). This may derive in an increase of the fitness of shrubs vs. grasses (because shrubs have deeper roots; Schulze et al. 1996; Schenk \& Jackson 2002; Phillips et al. 2019) and would explain the increasing dominance of shrublands vs grasslands associated to this threshold (Berdugo et al. 2020). Because water in deep soil layers is more stable (Noy-Meir 1973), increases in shrubs vs. grasses may be also an adaptation to increasing inter-annual fluctuations in rainfall patterns. These fluctuations increase with aridity (Le Houérou 2001; Feldman et al. 2018) and, at aridity levels 0.7 reach a coefficient of variation of $30 \%$ (Berdugo et al. 2020). This coefficient of variation value has been suggested as a limit for triggering vegetation instabilities (von Wehrden et al. 2012). Thus, a strong force selecting for plants with water uptake strategies able to uncouple productivity from immediate climatic conditions is suggested, and certainly evidenced by a decay of the vegetation sensitivity to climatic fluctuations in the soil disruption phase (Berdugo et al. 2020). Shall the erosive pathway be the main pathway triggering soil disruption phase, several and important confounding factors are relevant to investigate. For example, the increasing occurrence of extreme events (e.g., intense rainfall or dust storms) with climate change (Katz \& Brown 1992) may speed up soil erosion (Nearing et al. 2004). Soil parent material, disturbances such as landuse and soil age can also influence soil eco-hydrology (Jorgensen \& Gardner 1987) making this transformations highly context dependent. Finally, the role of topography on soil erosive processes introduces a further distortion factor at local scales (Xu et al. 2015b). 


\section{B. Shrub encroachment pathway}

The hypothesis underpinning this pathway is that vegetation shifts towards shrub dominated landscapes triggered by aridity scales to other ecosystem attributes due to the strong influence of vegetation type on multiple ecosystem attributes and functions. Shrub encroachment, also called woody encroachment or thickening is a global phenomenon especially apparent in drylands, characterised by an increase in the density and cover of native shrubs, particularly in grasslands and open woodlands (Goslee et al. 2003; Eldridge et al. 2011; Andela et al. 2013). Importantly, shifts in dominant plants towards shrub dominated landscapes is argued to be a critical shift between two alternative vegetation states underpinned by feedback processes (D'Odorico et al. 2012). Although not especially linked to aridity increases, but rather to other forms of land degradation such as grazing (Knapp et al. 2008), shrub encroachment has been related with climate change (Eldridge et al. 2011; Andela et al. 2013), and is explained by a number of feedback mechanisms with important links to aridity. There are three main feedbacks hypothesized to act on shrub encroachment. First, decreasing fire occurrence may favour shrubs in a grass-shrub competing environment because shrubs exhibit slower growth rates than grasses (D'Odorico et al. 2006), which are also are more flammable in dry periods (Van Wilgen et al. 2004). Although a decrease in fire occurrence is counterintuitive with increasing aridity (Piñol et al. 1998), the reduction of vegetation cover (and biomass) reduces the availability of fuel, thus decreasing fire occurrence (Pausas and Paula 2012). Accordingly, a recent analysis has shown how increases in drought reduced fire frequency across Africa (Wei et al. 2020). Second, certain shrubs are favoured by high near-surface nocturnal air temperatures preventing freezing cavitation (Pockman \& Sperry 1996). Once established, shrubs modify the energy balance around them by increasing air temperature (compared to grasses; He et al. 2010) in a process that promotes their own recruitment in detriment of that of grasses (D'Odorico et al. 2010). Although the effects of shrubs on microclimatic conditions vary depending on their traits vs. those of the grasses they replace (Maestre et al. 2009), the higher sensitivity of shrubs to freezing cavitation suggest that aridity increases, and the increase in temperatures they bring, may prevent freezing temperatures, initializing this feedback loop (see for instance the case of Larrea tridentata, a shrub encroachment prone species from North America, Pockman \& Sperry 2000; MartínezVilalta \& Pockman 2002). Third, grasslands often exhibit a continuous cover of the soil surface, protecting soils more efficiently than shrubs against erosion (Gyssels et al. 2005). As grasses exploit predominantly shallow soil nutrients (compared to shrubs, Schenk \& Jackson 2002), they are more sensitive to erosiondriven soil losses than shrubs (D'Odorico et al. 2012). Thus, the change in the erosion dynamics promoted by the replacement of grasses by shrubs also initialize a shrub-driven soil erosion feedback that further promotes the establishment of shrubs in detriment to that of grasses, and then shrubs create islands of fertility by capturing particles that enhance soil fertility around them (Wezel et al. 2000; Allington \& Valone 2014), further promoting their growth and subsequent recruitment. The three feedbacks described above likely act together and cannot be easily separated. The third feedback mechanism is of particular relevance because connects shrub encroachment with the erosive pathway described above, and may explain why shrub development may affect the soil system. However, it must be noted, that shrub encroachment is not always linked to negative impacts in soil, which largely depend on the traits of the encroaching shrubs (vs. those of grasses; Maestre et al. 2009; Eldridge et al. 2011; Eldridge and Soliveres 2015). Indeed, because their role on retaining nutrients shrubs can also act as important ecosystem engineers (Castro et al. 2002; Maestre et al. 2009) increasing the spatial heterogeneity of soil nutrients rather than diminishing the overall carbon stock of the system (Allington \& Valone 2014). For this reason, probably it is worth starting the exploration of aridity-induced shrub development using functional trait approaches. In particular, examining coordination between relevant plant traits along aridity gradients may help to unveil trade-offs between nutrient uptake strategies (with traits such as root morphology and nutrient content in leaves or nutrient resorption), the photosynthetic economic spectrum of leaves (with traits such as specific leaf area or rain use efficiency) and plant development (Gleason et al. 2013). By doing this, we may elucidate the functional structural changes that accompany shrub development during the soil disruption phase and understand whether aridity-induced shrub development is associated to certain type of shrubs with low nutrient content, poor decomposability of leaves or traits that are less efficient on retaining soil (as suggested by some authors Gross et al. 2010). A main factor favouring shrub encroachment is grazing, which enhances shrub development through the selection that herbivores make on plant types (Roques et al. 2001; Throop and Archer 2007; Daryanto et al. 2013). Besides, grazing may impede soil amelioration mediated by shrubs (Eldridge et al. 2013), acting on soil biogeochemical cycles and ultimately aggravating impacts of shrub encroachment. Thus, it is important to note that, if shrub development is a main trigger of soil disruption phase, grazed areas may overcome similar changes than those depicted for soil disruption phase at lower aridity values.

\section{C. The biogeochemical pathway}

The hypothesis underlying this pathway is that aridity imposes limits on biogeochemical cycles hampering the efficiency of nutrient cycling, impoverishing soils and affecting other ecosystem attributes. These limits on biogeochemical cycles may occur at two levels. First, microorganisms are key drivers of nutrient cycling and carbon stock regulation in soils (Manzoni et al. 2010; Trivedi et al. 2019; Soong et al. 


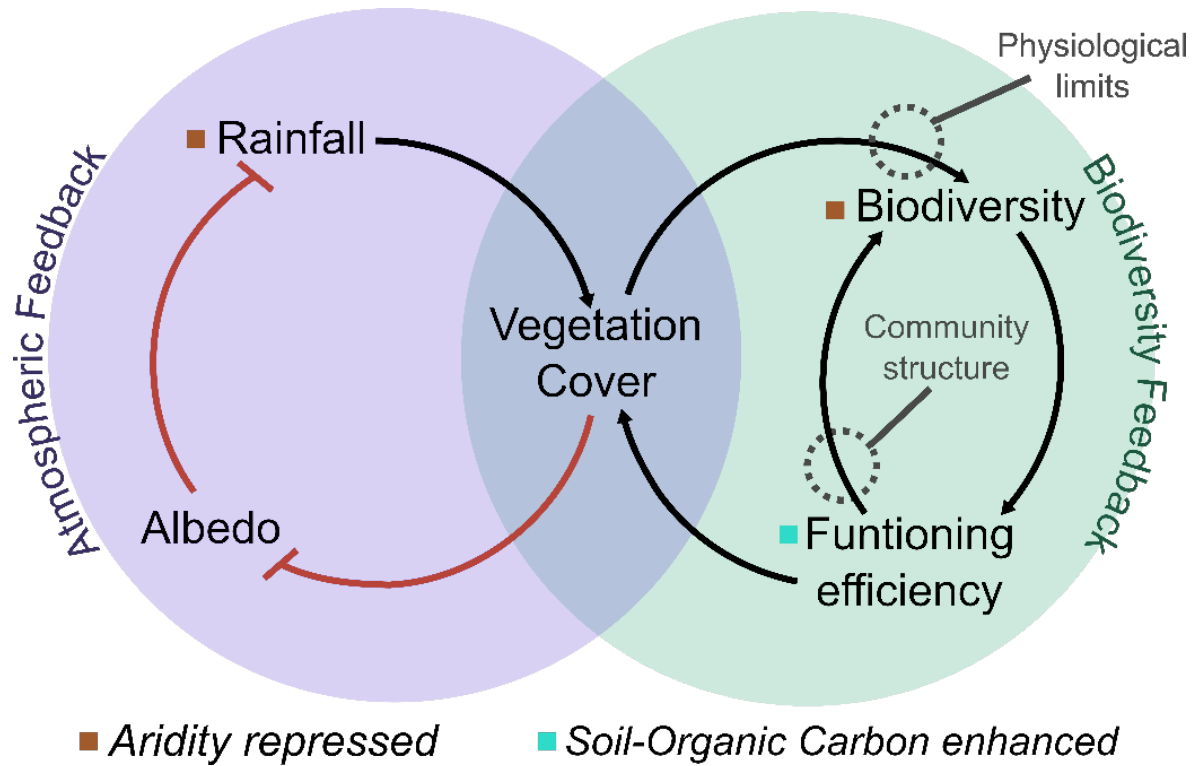

FIG. 3: Feedbacks hypothetically involved in systemic breakdown phase and grouped in two potential pathways involving biodiversity feedbacks (green) and atmospheric feedbacks (purple). Rest of legend as in figure 2.

2020). In particular, nutrient decomposition and cycling rates are substantially modulated by water availability (and thus by aridity; Delgado-Baquerizo et al. 2013b; Wang et al. 2014; Feng et al. 2019; Steidinger et al. 2019). Some groups of decomposers responsible for nutrient cycling, such as nematodes, are especially sensitive to aridity increases and may find a physiological limit in aridity levels around 0.7 (Xiong et al. 2019). The abundance and diversity of soil fungi and bacteria have also been found to decrease linearly with aridity across global drylands (Maestre et al. 2015), but this decrease is uneven across microbial groups, resulting in a drastic turnover of microbial composition at this aridity level (Delgado-Baquerizo et al. 2020). In particular, certain key microbial groups related with nutrient decomposition and redistribution such as ectomycorrhizal fungi exhibit abrupt decays in the soil disruption phase (Berdugo et al. 2020). Ectomycorrhizal fungi produce nitrogen-degrading enzymes allowing them a greater access to organic nitrogen sources and a more efficient nutrient storage in the soil than arbuscular mycorrhiza (Averill et al. 2014). Indeed, the relative abundance of arbuscular vs ectomycorrhizal fungi are thought to be indicative of contrasting ecosystem nutrient economy typologies (Phillips et al. 2013; Lu and Hedin 2019). The second level at which nutrient cycling may be affected is through litter inputs into the soil. Litter constitute the most important nutrient source to soils, thus changes in litter quantity or quality may affect importantly nutrients in soils. Nutrient inflows into the soil are paralleled by nutrient outflows in the form of erosion and plant nutrient absorption. Induced by low productivity rates inherited from vegetation decline phase and exacerbated by a decline in soil decomposition ability with increasing aridity, plant litter may become insufficient for the soil to maintain enough fertility, especially under increased soil erosion rates. In parallel, poor soil nutrient content may impact plant nutrition status, as evidenced by the decay in leaf nitrogen in this aridity level (Berdugo et al. 2020). This would promote strong fitness filtering force to preserve nitrogen through plant nutrient strategies (Delpiano et al. 2020) such as nutrient resorption, which change with increasing aridity in shrubs (Drenovsky et al. 2010; Delpiano et al. 2020). Moreover, recent studies suggest that systems strongly dependent on deep soil water availability (e.g., arid shrublands) may show a vertical decoupling of soil nutrient economy, entailing nutrient impoverishment because deep soil layers usually contain less nutrients than shallow layers (Querejeta et al. 2021). These two later mechanisms may affect litter quality and thus nutrient cycling. Importantly, both levels of nutrient cycling mechanisms (litter inputs and soil microbial activity) are tightly linked and may interact with each other in unexpected ways. For instance, mycorrhizal fungi also play an important role on the mobilization of nutrients to plants (Phillips et al. 2013). Thus, changes in their dominant type modulate plant responses to water and nutrient scarcity (Maestre et al. 2002; Azcón-aguilar et al. 2003; Lu \& Hedin 2019). In parallel, resource limitations impede plantmycorrhizal symbiosis (Johnson et al. 2010; Jassey et al. 2018). Besides, the species-specific role of plantmycorrhizal symbioses connects tightly the plant and mycorrhizal communities, so shifting plant communities usually involve shifts in mycorrhiza and, thus, the whole nutrient economy mechanisms (Bahram et al. 2020). As a final note, poor nutrient soils show less stable aggregates associated with certain mycorrhizal groups (Lehmann et al. 2020) and are more sensitive to erosion (Xiaojun et al. 2013) connecting biogeochemical mechanisms with the erosive pathway and closing the cycle among the three pathways described for the soil disruption phase. Although, as evidenced here, the biogeochemical pathway is of strategic concern for studying thresholds, their role as a feedback 
mechanism producing abrupt shifts is poorly understood. This is especially apparent in theoretical approaches, probably due to the notable complexity of the biogeochemical pathway. In our opinion, focusing model studies on broad ecosystem nutrient strategies marked by mycorrhizal types may simplify this complexity and promote a new generation of models that might be relevant for the study of aridity thresholds. Secondary factors that may influence mechanisms of the biogeochemical pathway include the soil legacy. Soils may sustain effects of plants up to 50 years after their extinction (Facelli and Brock 2000), supporting carbon and its role on driving erosion (Mora and Lázaro 2013). This memory of soil processes is a relevant but understudied driver of soil functioning, and is affecting directly dynamical rates of biogeochemical processes (e.g., soil respiration Hawkes et al. 2017; Dacal et al. 2019). Both the soil carbon content (Delgado-Baquerizo et al. 2017b) and soil microbial communities (Delgado-Baquerizo et al. 2017a) have been related to past climatic conditions extending soil legacy effects for centuries. Thus, fertile functional soils may undergo a soil disruption phase with a given inertia (inherited from soil characteristics prior aridification) that may significantly alter the incidence of abrupt shifts across temporal scales.

\section{MECHANISMS LINKED TO THE SYSTEMIC BREAKDOWN PHASE}

Mechanisms linked to the systemic breakdown phase should explain a massive vegetation collapse, which include abrupt declines in perennial plant species richness and cover that occur at aridity levels 0.82. Besides, these aridity values match those found in other studies showing a drastic turnover in dryland flora (Ulrich et al. 2014) entailing a shift in leaf strategies to cope with aridity stress from stress tolerance to stress avoidance (Carvajal et al. 2018; Berdugo et al. 2020). Our hypothesis is that there are physiological limits imposing drastic declines in vegetation cover, but that this is accelerated through feedbacks acting at plant-plant and plant-atmospheric levels. Thus, three different mechanisms may be relevant for this threshold (figure 3).

\section{A. Plant physiological limits}

The observed 0.82 aridity threshold is likely related to the physiological limits of plants (likely acting on survival rates), as soil water potential is bellow wilting point of vascular plants most of the year at this aridity level (Feldman et al. 2018; Bassiouni et al. 2020). Observed losses in plant species richness suggest that there is a strong convergence of these vegetation limits across species, likely driven by the narrowing of the niche to a sole limiting factor: water. Indeed, some studies highlight the nonlinear nature of species extinction due to convergent niche limits (Trisos et al. 2020), which may explain the abrupt loss of species observed in this threshold. It must be noted that, at aridity values 0.8 , the precipitation inter-annual variability also increases exponentially (Berdugo et al. 2020) and this uncertainty in precipitation may be even more detrimental for plant survival than the total amount of rainfall received. Some plants may be able to cope with this variability better than others (e.g., exhibiting avoidance strategies (Carvajal et al. 2018)). Indeed, it should be noted that the confounding factors that may influence the incidence of this phase, especially through temporal scales, are very similar to those of the vegetation decline phase. Thus, CO2 fertilization, and plant acclimation limits are still relevant but should be investigated on survival rates rather than on productivity or growth. Notably, the effects of $\mathrm{CO} 2$ fertilization in these arid environments may present strong and complex interactions with the extreme aridity of these sites (Peñuelas et al. 2017), thus areas crossing this thresholds are important candidates for prospecting research on this interaction in the coming years. Importantly, even when no plants can survive at very high aridity values, some organisms are able to thrive. For instance, absence of vegetation often induce development of biocrusts (lichens, algae and mosses that live in soil surface), which are able to photosynthetize and to cope with extreme climates in deserts (Belnap and Lange 2013). Importantly, these biocrusts have been known to impact ecosystem hydric cycles (Chamizo et al. 2013; Berdugo et al. 2014), act as facilitators of plant recruitment (Bowker 2007) or ameliorate soil functioning losses (Maestre et al. 2011; Delgado-Baquerizo et al. 2016). Thus, much more attention should be paid to biocrusts for preserving drylands facing the ecosystem breakdown phase. In these extremes it should also be noted that microclimatic conditions (existence of rocks, orientation of slopes, etc...) turn of very high relevance, providing key refuges for biocrusts and their associated fauna (Wierzchos et al. 2015).

\section{B. Biodiversity feedbacks}

At least part of the diversity loss found in this phase might be due to feedbacks occurring at the community level (i.e., on plant-plant interactions). Two mechanisms are important in this regard. First, interactions between plants shape their abundance and occurrence through competition and facilitation (Cornwell and Ackerly 2009). This structure of interactions may be highly organized in complex networks (Saiz and Alados 2011; Saiz et al. 2018), making the responses of a given plant species strongly depend on the responses of accompanying species. On one hand, the strong filtering force imposed by water scarcity may lead to a niche convergence that is usually associated to increasing frequency of competitive interactions between plants (the limiting similarity principle, (MacArthur \& Levins 1967)) and this may boost diversity losses due to competitive exclusion (Suding et al. 2003; Adler et al. 2010). This may occur at the community level, as suggested by increases in competition cf. facilitation as aridity increases in some studies (Berdugo et al. 2018, 2020), but also at local 


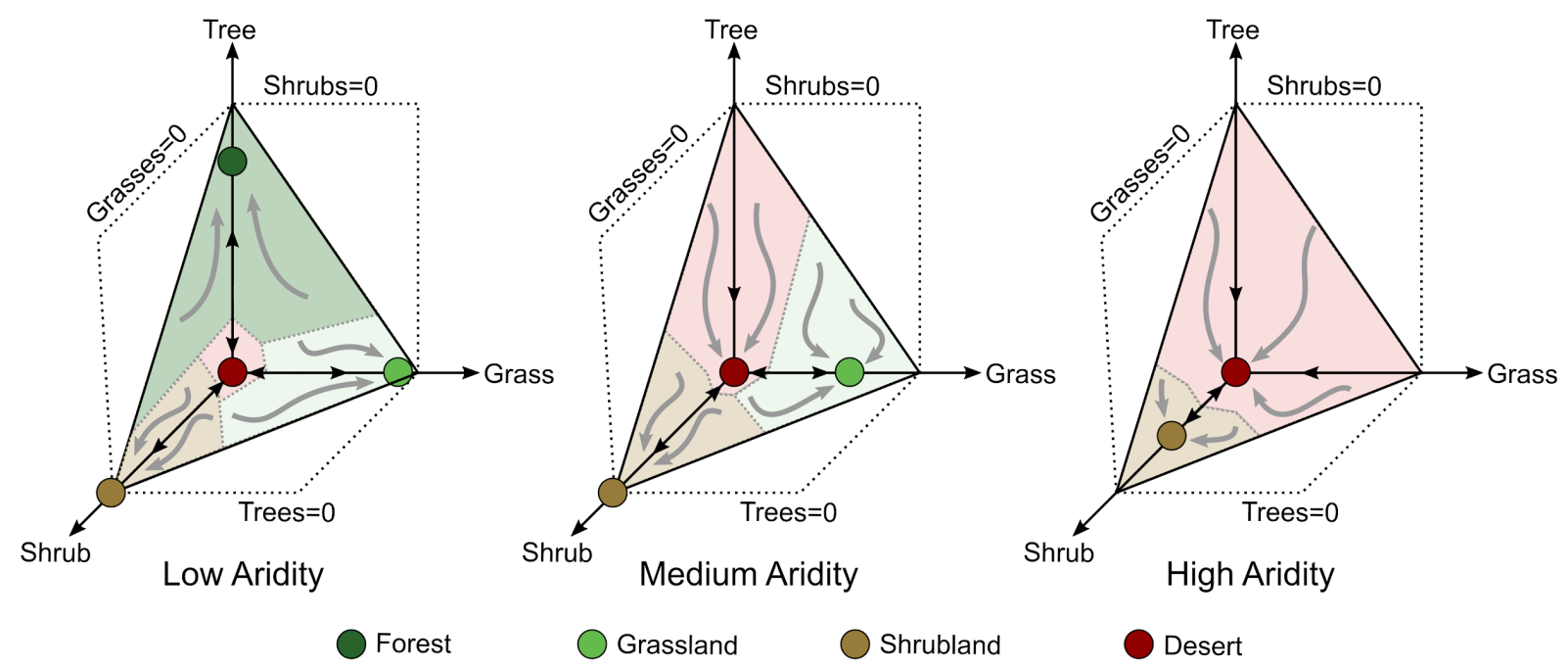

FIG. 4: Illustration on possible states in a landscape model simulating grasslands, shrublands, forests and deserts and their transitions depending on aridity. They depict how different initial conditions of the ecosystem (amount of trees, shrubs and grasses) may affect to the future evolution of the whole system. In low aridity regions, three different vegetation configurations may be stablished (forest, grasslands or shrublands) or even for external drivers the desert state (red dot). The final configuration will be the result of a continuous competition between the different plant species to be stablished (the different background colours indicate the conditions that leads the system to evolve towards configuration). Once the aridity is increased, less states can be achieved, and the previous situation of the system can lead the system to became decertified even if grassland or shrubland are possible configurations for that aridity index.

or individual scale in time, as suggested by some experiments in which imposed water shortages increases competitive exclusion (Alba et al. 2019). On the other hand, facilitative interactions are key for survival of the less adapted plants even in extreme environments (Berdugo et al. 2018), which makes plant-plant interaction networks nested on key species whose loss may produce cascading extinctions (Thébault et al. 2007; Dunne \& Williams 2009; Rocha et al. 2018). These cascading effects can even act through trophic levels, involving groups other than plants (Jones et al. 1996; Wright et al. 2004; Cuddington et al. 2011) and even affect microbial diversity (Saleem 2015). Thus it is important to understand species-species interactions in these communities, especially their strength and hierarchy, and studies aimed at understanding community interactions through networks in extreme environments are still insufficient and usually not assessing physiological limits of plants (something key in these very high aridity levels). Second, plant diversity is linked to higher levels of soil nutrient cycling and fertility (Maestre et al. 2012; Lefcheck et al. 2015), but also to productivity and ecosystem stability (Isbell et al. 2015; García-Palacios et al. 2018). Thus, reductions in diversity may induce instabilities at the ecosystem level and drastic reductions found in the breakdown phase may produce an acceleration of this collapse. Although this biodiversityecosystem functioning (BEF) relationship is relevant in all phases, it is key to investigate whether there might be a critical diversity point in which functioning decays on critical values at this particular aridity level. Indeed, some studies have uncovered an increase in the importance of BEF relationships as aridity increases (García-Palacios et al. 2018), pointing in this direction.

\section{C. Plant-atmosphere feedbacks}

Previous studies have suggested that a strong feedback between plants and atmospheric processes may promote the formation of desert-like conditions (Texier et al. 1997, 2000). These feedbacks build on the rationale that plants can have an important effect on climate at regional scales, usually increasing rainfall. Thus, reductions of plant cover, especially if abrupt, induce certain changes in the atmosphere that may prevent rainfall formation. This effect can be direct and indirect. First, vegetation may contribute to water recycling at local scales through evapotranspiration, thus increasing air humidity and enhance rainfall (Savenije 1995; Trenberth 1999). This is an important mechanism if air humidity is contributed importantly by vegetation recycling of water (Savenije 1995; Nieto et al. 2006), which may be the case in continental semi-deserts (Eltahir \& Bras 1996; Yosef et al. 2018; Branch \& Wulfmeyer 2019). Second, this modulation may be indirect by increases in land roughness (Sud et al. 1988) and soil water infiltration and availability (Shukla \& Mintz 1982; Alfieri et al. 2008) and by reductions in dust emissions (Ravi et al. 2011) and albedo (indeed, exponential increases in albedo are found in this aridity level (Berdugo et al. 2020) induced by vegetation at the landscape scale. Climate models that take into account these factors have shown that decreasing vegetation ultimately leads to a reduction of soil water incomes into the atmosphere, and thus reduce precipitation at regional scales (Xue 2006). Indeed, some models have shown that these feedbacks may be strong enough as to create alternative states associated with desertification (Wang \& Eltahir 2000a, 2000b; Zeng \& Neelin 2000). All these feedbacks point to a strong control of vegetation on 
TABLE II: Knowledge gaps and recommendations envisaged for thresholds mechanisms.

\begin{tabular}{|c|c|c|c|}
\hline Threshold & $\begin{array}{l}\text { Mechanisms } \\
\text { affected }\end{array}$ & Knowledge gap & Reccommendation \\
\hline \multirow{2}{*}{$\begin{array}{c}\text { Vegetation } \\
\text { decline phase }\end{array}$} & \multirow{2}{*}{ Plant physiology } & \multirow{2}{*}{$\begin{array}{c}\text { How communities of plants not } \\
\text { adapted to water scarcity may respond } \\
\text { to increasing dryness }\end{array}$} & $\begin{array}{l}\text { Investigate interactions between } \mathrm{CO} 2 \\
\text { increases and drying trends on plant } \\
\text { photosynthesis }\end{array}$ \\
\hline & & & $\begin{array}{l}\text { Investigate migration processes and turnover } \\
\text { change of the community in response to } \\
\text { increasing dryness }\end{array}$ \\
\hline \multirow{2}{*}{$\begin{array}{l}\text { Soil disruption } \\
\text { phase }\end{array}$} & \multirow{2}{*}{$\begin{array}{c}\text { Biogeochemical } \\
\text { pathway } \\
+ \text { shrub } \\
\text { encroachment } \\
\text { pathway } \\
\text { + erosive pathway }\end{array}$} & \multirow{2}{*}{$\begin{array}{l}\text { Dissentangle relative importance of the } \\
\text { three pathways on driving the soil } \\
\text { disruption, aiming at identifying the } \\
\text { most sensible, the most propagating } \\
\text { and the most deep mechanisms }\end{array}$} & $\begin{array}{l}\text { Manipulative experiments on litter } \\
\text { decomposition, soil microbial communities and } \\
\text { plant community changes to assess its impact } \\
\text { on the soil carbon cycling }\end{array}$ \\
\hline & & & $\begin{array}{l}\text { Models explicitly simulating soil, with special } \\
\text { emphasis on soil loss (erosion), plant-soil } \\
\text { feedbacks (biogeochemical pathway) and plant } \\
\text { morphological changes (encroachment) and } \\
\text { their relationships }\end{array}$ \\
\hline \multirow{4}{*}{$\begin{array}{l}\text { Systemic } \\
\text { breakdown } \\
\text { phase }\end{array}$} & $\begin{array}{l}\text { Physiological limits } \\
\text { + Biodiversity } \\
\text { feedbacks }\end{array}$ & $\begin{array}{l}\text { Do niche convergence scale through } \\
\text { plant-plant interaction networks to } \\
\text { drive massive extinction of species? }\end{array}$ & $\begin{array}{l}\text { Investigating physiological niche convergence } \\
\text { limits in conjunction with plant-plant interaction } \\
\text { matrix }\end{array}$ \\
\hline & $\begin{array}{l}\text { Biodiversity } \\
\text { feedbacks }\end{array}$ & $\begin{array}{l}\text { Is there a limit on diversity loss } \\
\text { unleashing instabilities in ecosystem } \\
\text { functioning a relevant driver of abrupt } \\
\text { vegetation collapse? }\end{array}$ & $\begin{array}{l}\text { Investigating the nonlinear nature of BEF at } \\
\text { the brink of systemic breakdown phase, } \\
\text { especially aiming at meassuring productivity } \\
\text { and temporal stability as ecosystem functions. }\end{array}$ \\
\hline & $\begin{array}{l}\text { Plant-Atmospheric } \\
\text { feedbacks }\end{array}$ & $\begin{array}{l}\text { Are vegetation-atmosphere feedbacks } \\
\text { globally important? }\end{array}$ & $\begin{array}{l}\text { Investigate rainfall patterns at regional scales } \\
\text { across the globe in relation with afforestation } \\
\text { practices. }\end{array}$ \\
\hline & Physiological limits & $\begin{array}{l}\text { How do biocrusts respond to systemic } \\
\text { breakdown phase? }\end{array}$ & $\begin{array}{l}\text { Asses the response of biocrust across aridity } \\
\text { gradients spanning he systemic breakdown } \\
\text { phase at global scales. }\end{array}$ \\
\hline \multirow[t]{2}{*}{ All } & \multirow[t]{2}{*}{ Legacy effects } & \multirow[t]{2}{*}{$\begin{array}{c}\text { What is the role of vegetation and soil } \\
\text { legacy effects on driving abrupt } \\
\text { responses? }\end{array}$} & $\begin{array}{l}\text { Field experiments and manipulative } \\
\text { experiments of climate change aiming at } \\
\text { crossing these thresholds should be } \\
\text { summarized globally to assess legacy effects } \\
\text { across different environments }\end{array}$ \\
\hline & & & $\begin{array}{l}\text { Models simulating transition phases on } \\
\text { different initialization conditions }\end{array}$ \\
\hline
\end{tabular}

atmosphere, thus suggesting that a transformation towards deserts is achieved rapidly at very high aridity levels and, most importantly, spanning vast spatial scales (Wang \& Eltahir 2000b; Yoshioka et al. 2005). This feedback also suggests that actions on systemic breakdown phase need to be done rapidly, otherwise increases in aridity itself may accelerate and reach very stable states impossible to revert such as deserts. On the other hand, preserving ecosystems at the brink of systemic breakdown phase, or even increasing their biomass through afforestation, may counteract aridity increases (Yosef et al. 2018; Branch \& Wulfmeyer 2019).

\section{CONCLUDING REMARKS AND FUTURE DIRECTIONS}

We reviewed the possible mechanisms that may cause aridity thresholds and we provide important insights on existing knowledge gaps that preclude a complete understanding of how thresholds emerge (Table II). Our review allows a general understanding on how drylands transform as aridity increases and explicitly considers the mechanisms that may be unleashing observed abrupt ecosystem responses (Figure 1). In the vegetation decline phase, we identified mainly plant physiological mechanisms in response to water scarcity as the main trigger. Here the major uncertainties rely on how plants will adapt to water scarcity in a context of rapid climate change. This response may be determinant to understand how plants will undergo this phase through time and may be conditioned to other factors such as ongoing increases in 
atmospheric CO2 concentration. Because an important proportion of world humid areas are currently transforming into drylands (around $3.5 \%$ of world surface according to the latest forecasts, Prăvălie et al., 2019) it is key to elucidate how increasing dryness will affect physiology of communities maladapted to water scarcity. For instance, the reduction in the photosynthetic capacity of plants at the vegetation decline phase may be determinant on initializing smooth cover reductions, unleashing responses in the soil disruption phase if vegetation cover decreases bellow a given point. Thus, if vegetation decline phase is smoothed or stabilized, the soil disruption phase may never happen even if aridity exceeds the 0.7 threshold. The opposite is also true: lack of viable populations of drought-adapted plants may unleash more drastic changes than depicted through spatial gradients in the vegetation decline phase, and derive in modifications of the aridity levels at which the next phase occurs.

The main gap of knowledge we have about the mechanisms operating soil disruption phase is that we do not know the main source of the changes among the three pathways identified: erosive pathway, shrub encroachment pathway or biogeochemical pathway. Future studies should be able to disentangle these pathways and find which pathway is actioned more easily by aridity increases (i.e., is more sensible to aridification), which one involves a higher number of ecosystem attributes (i.e., is most prone to propagate across ecosystem attributes) and which ones unleashes the most abrupt responses. This can be done using experimental approaches in manipulative experiments that need to take into account responses of soil microbial communities as a relevant (but usually understudied) trigger of abrupt ecosystem responses. Models lack here also clear precedents simulating both vegetation and soil changes, probably because the high complexity underpinning the functioning of plant-soil-microbiome feedbacks. Here we synthetized the main mechanisms and provide basic guidelines to simplify model assumptions. We think that models about soil disruption phase should explicitly model, soil disruption (exemplifying erosion), plant-soil dependence (exemplifying biogeochemical feedbacks) and plant morphological changes (exemplifying shrub-grass transitions). In the systemic breakdown phase, major knowledge gaps exist on the interaction between convergence of plant niche limits for survival and the structure of plant-plant interactions, which should be studied in conjunction. Also, limits on biodiversity ecosystem functioning (notably stability and productivity) should be investigated to assess whether part of the observed abrupt collapse of vegetation found is due to processes of niche complementarity. Vegetation-atmosphere feedbacks are also key, and the research done in this regard still lacks global assessments focused on this threshold. Experiments of afforestation already ongoing in deserts may provide a promising starting point that needs to be summarise at global scales. Finally, we still do not know how other organisms that colonize extreme environments, such as biological soil crusts, may respond to this threshold. This may provide a promising restora- tion tool that is currently being investigated at the theoretical level (Conde-Pueyo et al. 2020) but that lacks sufficient background from field and experimental approaches under very high aridity conditions. Although investigating mechanisms of thresholds one by one is good for a first approximation, more attention should be paid on how the phases are consecutively affected. For example, erosive feedbacks discussed in the soil disruption phase have been highlighted as a manifestation of desertification (Schlesinger et al. 1990; D'Odorico et al. 2013). However, the fact that vegetation is not reduced to zero in the soil disruption phase, might be related with the existence of shrubs (and some trees, Brandt et al. 2020), able to survive soil depletions by reaching water from deep soil layers. In other words, the presence of shrubs and trees can prevent desertification. If so, it might well be that ecosystems surpassing the soil disruption phase at aridity levels of 0.7 undergo massive vegetation mortality and pass directly to the responses expected for systemic breakdown phase if vegetation with access to deep water sources is not present. To enlighten this, we can understand the entire aridity gradient as a scenario where different stable states exemplifying landscape types contract and expand their attraction basins as aridity increases. This is exemplified in Figure 4 using a vegetation-transition model with forests, shrublands, grasslands and deserts. This model, although still lacking some key mechanisms related to soil, can show how resulting landscapes depend strongly on the initial landscape apart from the simulated aridity, which only defines the basins of attraction. This exercise exemplifies well a relevant understudied driver of abrupt transformations, which is the legacy effects of ecosystems. Legacy effects provide ecosystems with a certain memory and inertia that is a relevant secondary factor for all the aridity thresholds reviewed here. Understanding in detail these legacy effects of soil and vegetation is key for assessing the potential risk of experiencing abrupt temporal transformation as they make threshold occurrence at one particular site highly context dependent. For approaching legacy effects, although there are several manipulative and field experiments assessing legacy effects of plants and soils, we need an effort for summarizing them across different aridity levels in order to assess whether memory effects of vegetation/soil are dependent on aridity or change depending on the phase they operate. Given the current forecasts concerning the pace of global warming, an unprecedented scientific effort will be required to both expand our understanding of the fragilities of drylands and design ways to delay or event revert, their forthcoming collapse. This review provides a framework to a mechanistic understanding of aridity thresholds in drylands and points to future research directions by identifying key gaps of knowledge whose resolution may contribute to save the capacity of drylands to provide essential ecosystem services to millions of people in a more arid and unpredictable world. 


\section{Acknowledgements}

MB acknowledges support from Juan de la Cierva Formación fellowship program (FJCI-2018-036520-I) from Spanish Ministry of Science. B.V. and R.S have been funded by PR01018-EC-H2020-FET-Open MADONNA project. R.S. also counted with the support of the Santa Fe Institute, and the support of Secretaria d'Universitats i Recerca del Departament d'Economia i Coneixement de la Generalitat de Catalunya. FTM acknowledges support from the European Research Council grant agreement $n^{0}$ 647038 (BIODESERT) and from Generalitat Valenciana (CIDEGENT/2018/041). Authors declare no conflicts of interest.

\section{Author contributions}

$\mathrm{MB}$ conceived and organize the review. BV and $\mathrm{RS}$ made the figures and the modelling exercises for figure 4. All authors collaborated on writing the manuscript.

\section{Reference}

1. Abades SR, Gaxiola A, Marquet PA. 2014. Fire, percolation thresholds and the savanna forest transition: a neutral model approach. J Ecol 102:1386-93.

2. Adler PB, Ellner SP, Levine JM. 2010. Coexistence of perennial plants: an embarrassment of niches. Ecol Lett 13:1019-29.

3. Alba C, Fahey C, Flory SL. 2019. Global change stressors alter resources and shift plant interactions from facilitation to competition over time. Ecology 100:e02859.

4. Alfieri L, Claps P, D'Odorico P, Laio F, Over TM. 2008. An Analysis of the Soil Moisture Feedback on Convective and Stratiform Precipitation. J Hydrometeorol 9:280-91.

5. Allen M. 2009. Planetary boundaries: Tangible targets are critical. Nat Clim Chang 1:114-5.

6. Allington GRH, Valone TJ. 2014. Islands of fertility: A byproduct of grazing? Ecosystems $17: 127-41$

7. Andela N, Liu YY, van Dijk AIJM, de Jeu RAM, McVicar TR. 2013. Global changes in dryland vegetation dynamics (1988ndash;2008) assessed by satellite remote sensing: comparing a new passive microwave vegetation density record with reflective greenness data. Biogeosciences 10:6657-76.

8. Andersen T, Carstensen J, Hernández-García E, Duarte CM. 2009. Ecological thresholds and regime shifts: approaches to identification. Trends Ecol Evol 24:49-57.
9. Aparecido LMT, Woo S, Suazo C, Hultine KR, Blonder B. 2020. High water use in desert plants exposed to extreme heat. Ecol Lett 23:1189-200.

10. Averill C, Turner BL, Finzi AC. 2014. Mycorrhiza-mediated competition between plants and decomposers drives soil carbon storage. Nature 505:543-5.

11. Azcón-aguilar C, Palenzuela J, Roldán A. 2003. Analysis of the mycorrhizal potential in the rhizosphere of representative plant species from desertification-threatened Mediterranean shrublands. Appl Soil Ecol 22:29-37.

12. Bach EM, Baer SG, Meyer CK, Six J. 2010. Soil texture affects soil microbial and structural recovery during grassland restoration. Soil Biol Biochem 42:2182-91.

13. Bahram M, Netherway T, Hildebrand F, Pritsch K, Drenkhan R, Loit K, Anslan S, Bork P, Tedersoo L. 2020. Plant nutrient-acquisition strategies drive topsoil microbiome structure and function. New Phytol n/a.

14. Bassiouni M, Good SP, Still CJ, Higgins CW. 2020. Plant Water Uptake Thresholds Inferred From Satellite Soil Moisture. Geophys Res Lett 47:e2020GL087077.

15. Belnap J, Lange OL. 2013. Biological Soil Crusts: Structure, Function and Management. 2nd ed. (Belnap J, Lange OL, editors.). Berlin, Heidelberg: Springer, Berlin, Heidelberg

16. Berdugo M, Delgado-Baquerizo M, Soliveres S, Hernández-Clemente R, Zhao Y, Gaitán JJ, Gross N, Saiz H, Maire V, Lehmann A, Rillig MC, Solé R V, Maestre FT. 2020. Global Ecosystem thresholds driven by aridity. Science (80- ) 367:787-90

17. Berdugo M, Kéfi S, Soliveres S, Maestre FTFT. 2017. Plant spatial patterns identify alternative ecosystem multifunctionality states in global drylands. Nat Ecol Evol 1:3.

18. Berdugo M, Maestre FT, Kéfi S, Gross N, Le Bagousse-Pinguet Y, Soliveres S. 2018. Aridity preferences alter the relative importance of abiotic and biotic drivers on plant species abundance in global drylands. J Ecol 107:190-202.

19. Berdugo M, Soliveres S, Kéfi S, Maestre FT. 2019. The interplay between facilitation and habitat type drives spatial vegetation patterns in global drylands. Ecography (Cop) 42:755-67.

20. Berdugo M, Soliveres S, Maestre FTFT. 2014. Vascular plants and biocrusts modulate how abiotic factors affect wetting and drying events in drylands. Ecosystems 17:1242-56.

21. Botta F, Dahl-Jensen D, Rahbek C, Svensson A, Nogués-Bravo D. 2019. Abrupt Change in Climate and Biotic Systems. Curr Biol 29:R1045-54. 
22. Bowker MA. 2007. Biological Soil Crust Rehabilitation in Theory and Practice: An Underexploited Opportunity. Restor Ecol 15:13-23.

23. Branch O, Wulfmeyer V. 2019. Deliberate enhancement of rainfall using desert plantations. Proc Natl Acad Sci 116:18841 LP - 18847.

24. Brandt M, Tucker CJ, Kariryaa A, Rasmussen K, Abel C, Small J, Chave J, Rasmussen LV, Hiernaux P, Diouf AA, Kergoat L, Mertz O, Igel C, Gieseke F, Schöning J, Li S, Melocik K, Meyer J, Sinno S, Romero E, Glennie E, Montagu A, Dendoncker M, Fensholt R. 2020. An unexpectedly large count of trees in the West African Sahara and Sahel. Nature 587:78-82.

25. Breshears DD, Whicker JJ, Johansen MP, Pinder JE. 2003. Wind and water erosion and transport in semi-arid shrubland, grassland and forest ecosystems: quantifying dominance of horizontal wind-driven transport. Earth Surf Process Landforms 28:1189-209.

26. Brookshire ENJ, Weaver T. 2015. Long-term decline in grassland productivity driven by increasing dryness. Nat Commun 6 .

27. Bussotti F, Ferrini F, Pollastrini M, Fini A. 2014. The challenge of Mediterranean sclerophyllous vegetation under climate change: From acclimation to adaptation. Environ Exp Bot 103:80-98.

28. Carvajal DE, Loayza AP, Rios RS, Delpiano CA, Squeo FA. 2018. A hyper arid environment shapes an inverse pattern of the fast-slow plant economics spectrum for above-, but not belowground resource acquisition strategies. J Ecol in press.

29. Castro J, Zamora R, Hodar JA, Gomez JM. 2002. Use of Shrubs as Nurse Plants: A New Technique for Reforestation in Mediterranean Mountains. Restor Ecol 10:297-305.

30. Chamizo S, Cantón Y, Lázaro R, Domingo F. 2013. The role of biological soil crusts in soil moisture dynamics in two semiarid ecosystems with contrasting soil textures. J Hydrol.

31. Chappell A, Webb NP, Leys JF, Waters CM, Orgill S, Eyres MJ. 2019. Minimising soil organic carbon erosion by wind is critical for land degradation neutrality. Environ Sci Policy 93:43-52.

32. Cherlet M, Hutchinson C, Reynolds J, Hill J, Sommer S, von Maltitz G. 2018. World Atlas of Desertification. 3rd ed. (Cherlet M, Hutchinson C, Reynolds J, Hill J, Sommer S, von Maltitz G, editors.). Luxembourg: Publication Offise of the European Union

33. Choat B, Brodribb TJ, Brodersen CR, Duursma RA, López R, Medlyn BE. 2018. Triggers of tree mortality under drought. Nature 558:531-9.
34. Colazo JC, Buschiazzo D. 2015. The Impact of Agriculture on Soil Texture Due to Wind Erosion. L Degrad Dev 26:62-70.

35. Collins SL, Belnap J, Grimm NB, Rudgers JA, Dahm CN, D'Odorico P, Litvak M, Natvig DO, Peters DC, Pockman WT, others. 2014. A multiscale, hierarchical model of pulse dynamics in arid-land ecosystems. Annu Rev Ecol Evol Syst 45:397-419.

36. Conde-Pueyo N, Vidiella B, Sardanyés J, Berdugo M, Maestre FT, de Lorenzo V, Solé R. 2020. Synthetic Biology for Terraformation Lessons from Mars, Earth, and the Microbiome. Life 10 .

37. Cook BI, Mankin JS, Marvel K, Williams AP, Smerdon JE, Anchukaitis KJ. 2020. Twentyfirst Century Drought Projections in the CMIP6 Forcing Scenarios. Earth's Futur n/a:e2019EF001461.

38. Cornwell WK, Ackerly DD. 2009. Community assembly and shifts in plant trait distributions across an environmental gradient in coastal California. Ecol Monogr 79:109-26.

39. Cuddington K, Byers JE, Wilson WG, Hastings A. 2011. Ecosystem engineers: plants to protists. Academic Press

40. D'Odorico P, Bhattachan A, Davis KF, Ravi S, Runyan CW. 2013. Global desertification: drivers and feedbacks. Adv Water Resour 51:326-44.

41. D'Odorico P, Caylor K, Okin GS, Scanlon TM. 2007. On soil moisture-vegetation feedbacks and their possible effects on the dynamics of dryland ecosystems. J Geophys Res 112:G04010.

42. D'Odorico P, Fuentes JD, Pockman WT, Collins SL, He Y, Medeiros JS, DeWekker S, Litvak ME. 2010. Positive feedback between microclimate and shrub encroachment in the northern Chihuahuan desert. Ecosphere 1:art17.

43. D'Odorico P, Laio F, Ridolfi L. 2006. A Probabilistic Analysis of Fire-Induced Tree-Grass Coexistence in Savannas. Am Nat 167:E79-87.

44. D'Odorico P, Okin GS, Bestelmeyer BT. 2012. A synthetic review of feedbacks and drivers of shrub encroachment in arid grasslands. Ecohydrology 5:520-30.

45. Dacal M, Bradford MA, Plaza C, Maestre FT, García-Palacios P. 2019. Soil microbial respiration adapts to ambient temperature in global drylands. Nat Ecol Evol 3:232-8.

46. Damgaard C. 2019. A Critique of the Space-forTime Substitution Practice in Community Ecology. Trends Ecol Evol. 
47. Daryanto S, Eldridge DJ, Throop HL. 2013. Managing semi-arid woodlands for carbon storage: grazing and shrub effects on above-and belowground carbon. Agric Ecosyst Environ 169:1-11.

48. Delgado-Baquerizo M, Bissett A, Eldridge DJ, Maestre FT, He J-Z, Wang J-T, Hamonts K, Liu Y-R, Singh BK, Fierer N. 2017a. Palaeoclimate explains a unique proportion of the global variation in soil bacterial communities. Nat Ecol Evol 1:1339-47.

49. Delgado-Baquerizo M, Doulcier G, Eldridge DJ, Stouffer DB, Maestre FT, Wang J, Powell JR, Jeffries TC, Singh BK. 2020. Increases in aridity lead to drastic shifts in the assembly of dryland complex microbial networks. L Degrad Dev $31: 346-55$

50. Delgado-Baquerizo M, Eldridge DJ, Maestre FT, Karunaratne SB, Trivedi P, Reich PB, Singh BK. 2017b. Climate legacies drive global soil carbon stocks in terrestrial ecosystems. Sci Adv 3:e1602008.

51. Delgado-Baquerizo M, Maestre FT, Eldridge DJ, Bowker MA, Ochoa V, Gozalo B, Berdugo M, Val J, Singh BK. 2016. Biocrust-forming mosses mitigate the negative impacts of increasing aridity on ecosystem multifunctionality in drylands. New Phytol 209.

52. Delgado-Baquerizo M, Maestre FT, Gallardo A, Quero JL, Ochoa V, García-Gómez M, Escolar C, García-Palacios P, Berdugo M, Valencia E, Gozalo B, Noumi Z, Derak M, Wallenstein MD. 2013a. Aridity Modulates N Availability in Arid and Semiarid Mediterranean Grasslands. PLoS One 8.

53. Delgado-Baquerizo M, Maestre FTFT, Gallardo A, Bowker MAMA, Wallenstein MDMD, Quero JLJL, Ochoa V, Gozalo B, García-Gómez M, Soliveres S, García-Palacios P, Berdugo M, Valencia E, Escolar C, Arredondo T, Barraza-Zepeda C, Bran D, Carreira JAJA, Chaieb M, Conceicao AA, Derak M, Eldridge DJDJ, Escudero A, Espinosa CICI, Gaitán J, Gatica MGG, Gómez-González S, Guzman E, Gutiérrez JRJR, Florentino A, Hepper E, Hernández RMRM, Huber-Sannwald E, Jankju M, Liu J, Mau RLRL, Miriti M, Monerris J, Naseri K, Noumi Z, Polo V, Prina A, Pucheta E, Ramírez E, Ramírez-Collantes DADA, Romao R, Tighe M, Torres D, Torres-Díaz C, D. Ungar E, Val J, Wamiti W, Wang D, Zaady E, Conceiçao AA, Derak M, Eldridge DJDJ, Escudero A, Espinosa CICI, Gaitán J, Gatica MGG, Gómez-González S, Guzman E, Gutiérrez JRJR, Florentino A, Hepper E, Hernández RMRM, Huber-Sannwald E, Jankju M, Liu J, Mau RLRL, Miriti M, Monerris J, Naseri K, Noumi Z, Polo V, Prina A, Pucheta E, Ramírez E, Ramírez-Collantes DADA, Romao R, Tighe M, Torres D, TorresDíaz C, Ungar ED, Val J, Wamiti W, Wang D,
Zaady E. 2013b. Decoupling of soil nutrient cycles as a function of aridity in global drylands. Nature 502:672-6.

54. Delpiano CA, Prieto I, Loayza AP, Carvajal DE, Squeo FA. 2020. Different responses of leaf and root traits to changes in soil nutrient availability do not converge into a community-level plant economics spectrum. Plant Soil.

55. Drenovsky RE, James JJ, Richards JH. 2010. Variation in nutrient resorption by desert shrubs. J Arid Environ 74:1564-8.

56. Dunne JA, Williams RJ. 2009. Cascading extinctions and community collapse in model food webs. Philos Trans R Soc London B Biol Sci 364:1711-23.

57. Ehrenfeld JG, Ravit B, Elgersma K. 2005. Feedback in the plant-soil system. Annu Rev Environ Resour 30:75-115.

58. Eldridge DJ, Bowker MA, Maestre FT, Roger E, Reynolds JF, Whitford WG. 2011. Impacts of shrub encroachment on ecosystem structure and functioning: towards a global synthesis. Ecol Lett 14:709-22.

59. Eldridge DJ, Soliveres S. 2015. Are shrubs really a sign of declining ecosystem function? Disentangling the myths and truths of woody encroachment in Australia. Aust J Bot 62:594-608.

60. Eldridge DJ, Soliveres S, Bowker MA, Val J. 2013. Grazing dampens the positive effects of shrub encroachment on ecosystem functions in a semi-arid woodland. J Appl Ecol 50:1028-38.

61. Eltahir EAB, Bras RL. 1996. Precipitation recycling. Rev Geophys 34:367-78.

62. Elwell HA, Stocking MA. 1976. Vegetal cover to estimate soil erosion hazard in Rhodesia. Geoderma 15:61-70.

63. Facelli JM, Brock DJ. 2000. Patch dynamics in arid lands: localized effects of Acacia papyrocarpa on soils and vegetation of open woodlands of south Australia. Ecography (Cop) 23:479-91.

64. Feldman AF, Short Gianotti DJ, Konings AG, McColl KA, Akbar R, Salvucci GD, Entekhabi D. 2018. Moisture pulse-reserve in the soil-plant continuum observed across biomes. Nat Plants 4:1026-33.

65. Feng J, Wei K, Chen Z, Lü X-T, Tian J, Wang C, Chen L. 2019. Coupling and Decoupling of Soil Carbon and Nutrient Cycles Across an Aridity Gradient in the Drylands of Northern China: Evidence From Ecoenzymatic Stoichiometry. Global Biogeochem Cycles.

66. Ficetola GF, Denoël M. 2009. Ecological thresholds: an assessment of methods to identify abrupt changes in species-habitat relationships. Ecography (Cop) 32:1075-84. 
67. Fierer N. 2017. Embracing the unknown: disentangling the complexities of the soil microbiome. Nat Rev Microbiol 15:579-90.

68. Filatova T, Polhill JG, van Ewijk S. 2016. Regime shifts in coupled socio-environmental systems: Review of modelling challenges and approaches. Environ Model Softw 75:333-47.

69. Francis CF, Thornes JB. 1990. Runoff hydrographs from three Mediterranean vegetation covers. In: Thornes JB, editor. Vegetation and Erosion. Chichester: Jhon Wiley Sons. pp 363-85.

70. García-Palacios P, Gross N, Gaitán J, Maestre FT. 2018. Climate mediates the biodiversity-ecosystem stability relationship globally. Proc Natl Acad Sci.

71. Gillette DA, Blifford Jr. IH, Fryrear DW. 1974. The influence of wind velocity on the size distributions of aerosols generated by the wind erosion of soils. J Geophys Res 79:4068-75.

72. Gleason SM, Butler DW, Waryszak P. 2013. Shifts in Leaf and Stem Hydraulic Traits across Aridity Gradients in Eastern Australia. Int J Plant Sci 174:1292-301.

73. Goslee SC, Havstad KM, Peters DPC, Rango A, Schlesinger WH. 2003. High-resolution images reveal rate and pattern of shrub encroachment over six decades in New Mexico, USA. J Arid Environ 54:755-67.

74. Groffman PM, Baron JS, Blett T, Gold AJ, Goodman I, Gunderson LH, Levinson BM, Palmer MA, Paerl HW, Peterson GD, others. 2006. Ecological thresholds: the key to successful environmental management or an important concept with no practical application? Ecosystems 9:1-13.

75. Gross N, Liancourt P, Choler P, Suding KN, Lavorel S. 2010. Strain and vegetation effects on local limiting resources explain the outcomes of biotic interactions. Perspect Plant Ecol Evol Syst 12:9-19.

76. Gyssels G, Poesen J, Bochet E, Li Y. 2005. Impact of plant roots on the resistance of soils to erosion by water: a review. Prog Phys Geogr Earth Environ 29:189-217.

77. Hawkes C V, Waring BG, Rocca JD, Kivlin SN. 2017. Historical climate controls soil respiration responses to current soil moisture. Proc Natl Acad Sci 114:6322 LP - 6327.

78. He B, Wang S, Guo L, Wu X. 2019. Aridity change and its correlation with greening over drylands. Agric For Meteorol 278:107663.

79. He Y, D'Odorico P, De Wekker SFJ, Fuentes JD, Litvak M. 2010. On the impact of shrub encroachment on microclimate conditions in the northern Chihuahuan desert. J Geophys Res Atmos 115 .
80. Hillebrand H, Donohue I, Harpole WS, Hodapp D, Kucera M, Lewandowska AM, Merder J, Montoya JM, Freund JA. 2020. Thresholds for ecological responses to global change do not emerge from empirical data. Nat Ecol Evol.

81. Hirota M, Holmgren M, Van Nes EH, Scheffer M. 2011. Global resilience of tropical forest and savanna to critical transitions. Science (80- ) $334: 232-5$.

82. Holling CS. 1973. Resilience and Stability of Ecological Systems. Annu Rev Ecol Syst 4:1-23.

83. Hou J, Dijkstra FA, Zhang X, Wang C, Lü X, Wang P, Han X, Cheng W. 2019. Aridity thresholds of soil microbial metabolic indices along a $3,200 \mathrm{~km}$ transect across arid and semi-arid regions in Northern China. PeerJ 7:e6712.

84. Le Houérou HN. 2001. Biogeography of the arid steppeland north of the Sahara. J Arid Environ 48:103-28.

85. Huang J, Li Y, Fu C, Chen F, Fu Q, Dai A, Shinoda M, Ma Z, Guo W, Li Z, Zhang L, Liu Y, Yu H, He Y, Xie Y, Guan X, Ji M, Lin L, Wang S, Yan H, Wang G. 2017. Dryland climate change: Recent progress and challenges. Rev Geophys 55:719-78.

86. Huang J, Yu H, Guan X, Wang G, Guo R. 2015. Accelerated dryland expansion under climate change. Nat Clim Chang 6:166-71.

87. Isbell F, Craven D, Connolly J, Loreau M, Schmid B, Beierkuhnlein C, Bezemer TM, Bonin C, Bruelheide H, De Luca E, Ebeling A, Griffin JN, Guo Q, Hautier Y, Hector A, Jentsch A, Kreyling J, Lanta V, Manning P, Meyer ST, Mori AS, Naeem S, Niklaus PA, Polley HW, Reich PB, Roscher C, Seabloom EW, Smith MD, Thakur MP, Tilman D, Tracy BF, Van Der Putten WH, Van Ruijven J, Weigelt A, Weisser WW, Wilsey B, Eisenhauer N. 2015. Biodiversity increases the resistance of ecosystem productivity to climate extremes. Nature 526.

88. Jassey VEJ, Reczuga MK, Zielińska M, Słowińska S, Robroek BJM, Mariotte P, Seppey CVW, Lara E, Barabach J, Słowiński M, Bragazza L, Chojnicki BH, Lamentowicz M, Mitchell EAD, Buttler A. 2018. Tipping point in plant-fungal interactions under severe drought causes abrupt rise in peatland ecosystem respiration. Glob Chang Biol 24:972-86.

89. Johnson NC, Wilson GWT, Bowker MA, Wilson JA, Miller RM. 2010. Resource limitation is a driver of local adaptation in mycorrhizal symbioses. Proc Natl Acad Sci 107:2093 LP - 2098.

90. Jones CG, Lawton JH, Shachak M. 1996. Organisms as Ecosystem Engineers BT - Ecosystem Management: Selected Readings. In: Samson FB, Knopf FL, editors. New York, NY: Springer New York. pp 130-47. 
91. Jorgensen DW, Gardner TW. 1987. Infiltration capacity of disturbed soils: temporal change and lithologic control. JAWRA J Am Water Resour Assoc 23:1161-72.

92. Katz RW, Brown BG. 1992. Extreme events in a changing climate: Variability is more important than averages. Clim Change 21:289-302.

93. Kéfi S, Rietkerk M, Alados CL, Pueyo Y, Papanastasis VP, ElAich A, De Ruiter PC. 2007a. Spatial vegetation patterns and imminent desertification in Mediterranean arid ecosystems. Nature 449:213-7.

94. Kéfi S, Rietkerk M, van Baalen M, Loreau M. 2007b. Local facilitation, bistability and transitions in arid ecosystems. Theor Popul Biol 71:367-79.

95. Knapp AK, Briggs JM, Collins SL, Archer SR, Bret-Harte MS, Ewers BE, Peters DP, Young DR, Shaver GR, Pendall E, Cleary MB. 2008. Shrub encroachment in North American grasslands: shifts in growth form dominance rapidly alters control of ecosystem carbon inputs. Glob Chang Biol 14:615-23.

96. Kreyling J, Jentsch A, Beier C. 2014. Beyond realism in climate change experiments: gradient approaches identify thresholds and tipping points. Ecol Lett 17:125-e1.

97. Lal R. 2019. Accelerated Soil erosion as a source of atmospheric CO2. Soil Tillage Res 188:35-40.

98. Lefcheck JS, Byrnes JEK, Isbell F, Gamfeldt L, Griffin JN, Eisenhauer N, Hensel MJS, Hector A, Cardinale BJ, Duffy JE. 2015. Biodiversity enhances ecosystem multifunctionality across trophic levels and habitats. Nat Commun 6.

99. Lehmann A, Zheng W, Ryo M, Soutschek K, Roy J, Rongstock R, Maaß S, Rillig MC. 2020. Fungal Traits Important for Soil Aggregation . Front Microbiol 10:2904.

100. Li J, Okin GS, Epstein HE. 2009. Effects of enhanced wind erosion on surface soil texture and characteristics of windblown sediments. J Geophys Res Biogeosciences 114.

101. Liu L, Gudmundsson L, Hauser M, Qin D, Li S, Seneviratne SI. 2020. Soil moisture dominates dryness stress on ecosystem production globally. Nat Commun 11:4892.

102. Lu M, Hedin LO. 2019. Global plant-symbiont organization and emergence of biogeochemical cycles resolved by evolution-based trait modelling. Nat Ecol Evol.

103. Lu X, Wang L, McCabe MF. 2016. Elevated CO2 as a driver of global dryland greening. Sci Rep 6:20716.
104. Luo W, Sardans J, Dijkstra FA, Peñuelas J, Lü X-T, Wu H, Li M-H, Bai E, Wang Z, Han X, others. 2016. Thresholds in decoupled soilplant elements under changing climatic conditions. Plant Soil:1-15.

105. MacArthur R, Levins R. 1967. The limiting similarity, convergence, and divergence of coexisting species. Am Nat:377-85.

106. Maestre FT., Quero JL., Gotelli NJ., Escudero A, Ochoa V, Delgado-Baquerizo M, GarcíaGómez M, Bowker MAMA, Soliveres S, Escolar C, others, García-Palacios P, Berdugo M, Valencia E, Gozalo B, Gallardo A, Aguilera L, Arredondo T, Blones J, Boeken B, Bran D, Conceição AA, Cabrera O, Chaieb M, Derak M, Eldridge DJ, Espinosa CI, Florentino A, Gaitán J, Gabriel Gatica M, Ghiloufi W, Gómez-González S, Gutiérrez JR, Hernández RM, Huang X, Huber-Sannwald E, Jankju M, Miriti M, Monerris J, Mau RL, Morici E, Naseri K, Ospina A, Polo V, Prina A, Pucheta E, Ramírez-Collantes DA, Romão R, Tighe M, Torres-Díaz C, Val J, Veiga JP, Wang D, Zaady E. 2012. Plant species richness and ecosystem multifunctionality in global drylands. Science (80- ) 335:214-8.

107. Maestre FT, Bautista S, Cortina J, Díaz G, Honrubia M, Vallejo R. 2002. Microsite and mycorrhizal inoculum effects on the establishment of Quercus coccifera in a semi-arid degraded steppe. Ecol Eng 19:289-95.

108. Maestre FT, Bowker MA, Cantón Y, CastilloMonroy AP, Cortina J, Escolar C, Escudero A, Lázaro R, Martínez I. 2011. Ecology and functional roles of biological soil crusts in semiarid ecosystems of Spain. J Arid Environ 75:1282-91.

109. Maestre FT, Bowker MA, Puche MD, Belén Hinojosa M, Martínez I, García-Palacios P, Castillo AP, Soliveres S, Luzuriaga AL, Sánchez AM, others. 2009. Shrub encroachment can reverse desertification in semi-arid Mediterranean grasslands. Ecol Lett 12:930-41.

110. Maestre FT, Delgado-Baquerizo M, Jeffries TC, Eldridge DJ, Ochoa V, Gozalo B, Quero JL, García-Gómez M, Gallardo A, Ulrich W, Bowker MA, Arredondo T, Barraza C, Bran D, Florentino A, Gaitán J, Gutiérrez JR, HuberSannwald E, Jankju M, Mau RL, Miriti M, Naseri K, Ospina A, Stavi I, Wang D, Woods NN, Yuan X, Zaady E, Singh BK. 2015. Increasing aridity reduces soil microbial diversity and abundance in global drylands. Proc Natl Acad Sci 112:15684-9.

111. Maestre FT, Eldridge DJ, Soliveres S, Kéfi S, Delgado-Baquerizo M, Bowker MAMA, GarcíaPalacios P, Gaitán J, Gallardo A, Lázaro R, Berdugo M. 2016. Structure and Functioning of Dryland Ecosystems in a Changing World. Annu Rev Ecol Evol Syst 47:215-37. 
112. Mansfield TA, Freer-Smith PH. 1984. The role of stomata in resistance mechanisms. In: Koziol MJ, Whatley FR, editors. Gaseous Air Pollutants and Plant Metabolism. 1st ed. Elsevier. Butterworth-Heinemann. pp 131-46.

113. Manzoni S, Trofymow JA, Jackson RB, Porporato A. 2010. Stoichiometric controls on carbon, nitrogen, and phosphorus dynamics in decomposing litter. Ecol Monogr 80:89-106.

114. Martínez-Vilalta J, Pockman WT. 2002. The vulnerability to freezing-induced xylem cavitation of Larrea tridentata (Zygophyllaceae) in the Chihuahuan desert. Am J Bot 89:1916-24.

115. Mavimbela SSW, van Rensburg LD. 2017. Characterizing infiltration and internal drainage of South African dryland soils. Earth Surf Process Landforms 42:414-25.

116. May RM. 1976. Simple mathematical models with very complicated dynamics. Nature 261:459-67.

117. McIntire EJB, Fajardo A. 2009. Beyond description: the active and effective way to infer processes from spatial patterns. Ecology 90:46-56.

118. Middleton N, Stringer L, Goudie A, Thomas D. 2011. The forgotten billion: MDG achievement in the drylands. In: United Nations Convention to Combat Desertification, Bonn.

119. Middleton NJ, Thomas DS. 1992. World Atlas of Desertification. London: United Nations Environment Programme / Edward Arnold

120. Mora JL, Lázaro R. 2013. Evidence of a threshold in soil erodibility generating differences in vegetation development and resilience between two semiarid grasslands. J Arid Environ 89:57-66.

121. Morris KA. 2011. What is hysteresis? Appl Mech Rev 64:50801.

122. Munson SM, Belnap J, Okin GS. 2011. Responses of wind erosion to climate-induced vegetation changes on the Colorado Plateau. Proc Natl Acad Sci 108:3854 LP - 3859.

123. Naipal V, Ciais P, Wang Y, Lauerwald R, Guenet B, Van Oost K. 2018. Global soil organic carbon removal by water erosion under climate change and land use change during ADthinsp;1850-2005. Biogeosciences 15:4459-80.

124. Nearing MA, Pruski FF,;Neal MR. 2004. Expected climate change impacts on soil erosion rates: A review. J Soil Water Conserv 59:43 LP $-50$.

125. Neilson RP, Pitelka LF, Solomon AM, Nathan R, Midgley GF, Fragoso JM V, Lischke H, Thompson K. 2005. Forecasting Regional to
Global Plant Migration in Response to Climate Change. Bioscience 55:749-59.

126. Nemani RR, Keeling CD, Hashimoto H, Jolly WM, Piper SC, Tucker CJ, Myneni RB, Running SW. 2003. Climate-Driven Increases in Global Terrestrial Net Primary Production from 1982 to 1999. Science (80- ) 300:1560 LP - 1563.

127. van Nes EH, Arani BMSS, Staal A, van der Bolt B, Flores BM, Bathiany S, Scheffer M. 2016. What Do You Mean, 'Tipping Point'? Trends Ecol Evol.

128. Nieto R, Gimeno L, Trigo RM. 2006. A Lagrangian identification of major sources of Sahel moisture. Geophys Res Lett 33.

129. Noy-Meir I. 1973. Desert Ecosystems: Environment and Producers. Annu Rev Ecol Syst $4: 25-51$.

130. Nunes A, Köbel M, Pinho P, Matos P, Bello F de, Correia O, Branquinho C. 2017. Which plant traits respond to aridity? A critical step to assess functional diversity in Mediterranean drylands. Agric For Meteorol.

131. Pausas JG, Paula S. 2012. Fuel shapes the fire-climate relationship: evidence from Mediterranean ecosystems. Glob Ecol Biogeogr 21:1074-82.

132. Peñuelas J, Ciais P, Canadell JG, Janssens IA, Fernández-Martínez M, Carnicer J, Obersteiner M, Piao S, Vautard R, Sardans J. 2017. Shifting from a fertilization-dominated to a warmingdominated period. Nat Ecol Evol 1:1438-45.

133. Phillips ML, McNellis BE, Allen MF, Allen EB. 2019. Differences in root phenology and water depletion by an invasive grass explains persistence in a Mediterranean ecosystem. Am J Bot 106:1210-8.

134. Phillips RP, Brzostek E, Midgley MG. 2013. The mycorrhizal-associated nutrient economy: a new framework for predicting carbon-nutrient couplings in temperate forests. New Phytol 199:41-51.

135. Piñol J, Terradas J, Lloret F. 1998. Climate Warming, Wildfire Hazard, and Wildfire Occurrence in Coastal Eastern Spain. Clim Change $38: 345-57$.

136. Pockman WT, Sperry JS. 1996. Freezinginduced xylem cavitation and the northern limit of Larrea tridentata. Oecologia 109:19-27.

137. Pockman WT, Sperry JS. 2000. Vulnerability to Xylem Cavitation and the Distribution of Sonoran Desert Vegetation. Am J Bot 87:1287-99.

138. Prăvălie R, Bandoc G, Patriche C, Sternberg T. 2019. Recent changes in global drylands: Evidences from two major aridity databases. CATENA 178:209-31. 
139. Querejeta JI, Ren W, Prieto I. 2021. Vertical decoupling of soil nutrients and water under climate warming reduces plant cumulative nutrient uptake, water use efficiency and productivity. New Phytol n/a.

140. Quiroga ER, Golluscio R, Blanco L, Fernández R. 2010. Aridity and grazing as convergent selective forces: an experiment with an Arid Chaco bunchgrass. Ecol Appl 20:1876-89.

141. Ravi S, Breshears DD, Huxman TE, D'Odorico P. 2010. Land degradation in drylands: Interactions among hydrologic-aeolian erosion and vegetation dynamics. Geomorphology 116:236-45.

142. Ravi S, D'Odorico P, Breshears DD, Field JP, Goudie AS, Huxman TE, Li J, Okin GS, Swap RJ, Thomas AD, Van Pelt S, Whicker JJ, Zobeck TM. 2011. Aeolian processes and the biosphere. Rev Geophys 49:n/a-n/a.

143. Ravi S, D'Odorico P, Okin GS. 2007. Hydrologic and aeolian controls on vegetation patterns in arid landscapes. Geophys Res Lett 34:L24S23.

144. Ravi S, D'Odorico P, Wang L, Collins S. 2008. Form and function of grass ring patterns in arid grasslands: the role of abiotic controls. Oecologia 158:545-55.

145. Reich PB. 2014. The world-wide 'fast-slow' plant economics spectrum: A traits manifesto. J Ecol 102:275-301.

146. Rocha JC, Peterson G, Bodin Ö, Levin S. 2018. Cascading regime shifts within and across scales. Science (80- ) 362:1379-83.

147. Rockström J, Steffen W, Noone K, Persson A, Chapin III FS, Lambin E, Lenton TM, Scheffer M, Folke C, Schellnhuber HJ. 2009. Planetary boundaries: exploring the safe operating space for humanity. Ecol Soc 14.

148. Roques KG, O'Connor TG, Watkinson AR. 2001. Dynamics of shrub encroachment in an African savanna: relative influences of fire, herbivory, rainfall and density dependence. J Appl Ecol 38:268-80.

149. Saiz H, Alados CL. 2011. Effect of Stipa tenacissima L. on the structure of plant co-occurrence networks in a semi-arid community. Ecol Res 26:595-603.

150. Saiz H, Gómez-Gardeñes J, Borda JP, Maestre FT. 2018. The structure of plant spatial association networks is linked to plant diversity in global drylands. J Ecol 106:1443-53.

151. Saleem M. 2015. Loss of Microbiome Ecological Niches and Diversity by Global Change and Trophic Downgrading BT - Microbiome Community Ecology: Fundamentals and Applications. In: Saleem M, editor. Cham: Springer International Publishing. pp 89-113.
152. Savenije HHG. 1995. New definitions for moisture recycling and the relationship with land-use changes in the Sahel. J Hydrol 167:57-78.

153. Schaffer WM. 1981. Ecological Abstraction: The Consequences of Reduced Dimensionality in Ecological Models. Ecol Monogr 51:383-401.

154. Scheffer M, Barrett S, Carpenter SR, Folke C, Green AJ, Holmgren M, Hughes TP, Kosten S, van de Leemput IA, Nepstad DC, van Nes EH, Peeters ETHM, Walker B. 2015. Creating a safe operating space for iconic ecosystems. Science (80- ) 347:1317 LP - 1319.

155. Scheffer M, Carpenter S, Foley JA, Folke C, Walker B. 2001. Catastrophic shifts in ecosystems. Nature 413:591-6.

156. Scheffer M, Carpenter SR. 2003. Catastrophic regime shifts in ecosystems: linking theory to observation. Trends Ecol Evol 18:648-56.

157. Scheffer M, Hirota M, Holmgren M, Van Nes EH, Chapin FS. 2012. Thresholds for boreal biome transitions. Proc Natl Acad Sci 109:21384-9.

158. Schenk HJ, Jackson RB. 2002. THE GLOBAL BIOGEOGRAPHY OF ROOTS. Ecol Monogr 72:311-28.

159. Schlaepfer DR, Bradford JB, Lauenroth WK, Munson SM, Tietjen B, Hall SA, Wilson SD, Duniway MC, Jia G, Pyke DA, Lkhagva A, Jamiyansharav K. 2017. Climate change reduces extent of temperate drylands and intensifies drought in deep soils. Nat Commun 8:14196.

160. Schlesinger WH, Reynolds JF, Cunningham GL, Huenneke LF, Jarrell WM, Virginia RA, Whitford WG. 1990. Biological feedbacks in global desertification. Science (80- ) 247:1043-8.

161. Schulze ED, Mooney HA, Sala OE, Jobbagy E, Buchmann N, Bauer G, Canadell J, Jackson RB, Loreti J, Oesterheld M, Ehleringer JR. 1996. Rooting depth, water availability, and vegetation cover along an aridity gradient in Patagonia. Oecologia 108:503-11.

162. Schwinning S, Ehleringer JR. 2001. Water use trade-offs and optimal adaptations to pulsedriven arid ecosystems. J Ecol 89:464-80.

163. Shukla J, Mintz Y. 1982. Influence of LandSurface Evapotranspiration on the Earth039;s Climate. Science (80- ) 215:1498 LP - 1501.

164. Soong JL, Fuchslueger L, Marañon-Jimenez S, Torn MS, Janssens IA, Penuelas J, Richter A. 2020. Microbial carbon limitation: The need for integrating microorganisms into our understanding of ecosystem carbon cycling. Glob Chang Biol 26:1953-61. 
165. Steffen W, Richardson K, Rockström J, Cornell SE, Fetzer I, Bennett EM, Biggs R, Carpenter SR, de Vries W, de Wit CA, Folke C, Gerten D, Heinke J, Mace GM, Persson LM, Ramanathan V, Reyers B, Sörlin S. 2015. Planetary boundaries: Guiding human development on a changing planet. Science (80- ) 347:1259855.

166. Steidinger BS, Crowther TW, Liang J, Van Nuland ME, Werner GDA, Reich PB, Nabuurs GJ, de-Miguel S, Zhou M, Picard N, Herault B, Zhao X, Zhang C, Routh D, Peay KG, Abegg M, Adou Yao CY, Alberti G, Almeyda Zambrano A, Alvarez-Davila E, Alvarez-Loayza P, Alves LF, Ammer C, Antón-Fernández C, AraujoMurakami A, Arroyo L, Avitabile V, Aymard G, Baker T, Bałazy R, Banki O, Barroso J, Bastian M, Bastin J-F, Birigazzi L, Birnbaum P, Bitariho R, Boeckx P, Bongers F, Bouriaud O, Brancalion PHS, Brandl S, Brearley FQ, Brienen R, Broadbent E, Bruelheide H, Bussotti F, Cazzolla Gatti R, Cesar R, Cesljar G, Chazdon R, Chen HYH, Chisholm C, Cienciala E, Clark CJ, Clark D, Colletta G, Condit R, Coomes D, Cornejo Valverde F, Corral-Rivas JJ, Crim P, Cumming J, Dayanandan S, de Gasper AL, Decuyper M, Derroire G, DeVries B, Djordjevic I, Iêda A, Dourdain A, Obiang NLE, Enquist B, Eyre T, Fandohan AB, Fayle TM, Feldpausch TR, Finér L, Fischer M, Fletcher C, Fridman J, Frizzera L, Gamarra JGP, Gianelle D, Glick HB, Harris D, Hector A, Hemp A, Hengeveld G, Herbohn J, Herold M, Hillers A, Honorio Coronado EN, Huber M, Hui C, Cho H, Ibanez T, Jung I, et al. 2019. Climatic controls of decomposition drive the global biogeography of forest-tree symbioses. Nature 569:404-8.

167. Stocker TF, Qin D, Plattner GK, Tignor M, Allen SK, Boschung J, Nauels A, Xia Y, Bex B, Midgley BM. 2013. Climate change 2013: the physical science basis. Contribution of working group I to the fifth assessment report of the intergovernmental panel on climate change. Geneva: Cambridge University Press

168. Stout JE. 2007. Simultaneous observations of the critical aeolian threshold of two surfaces. Geomorphology 85:3-16.

169. Sud YC, Shukla J, Mintz Y. 1988. Influence of Land Surface Roughness on Atmospheric Circulation and Precipitation: A Sensitivity Study with a General Circulation Model. J Appl Meteorol 27:1036-54.

170. Suding KN, Goldberg DE, Hartman KM. 2003. Relationships among species traits: separating levels of response and and identifying linkages to abundance. Ecology 84:1-16.

171. Suding KN, Gross KL, Houseman GR. 2004. Alternative states and positive feedbacks in restoration ecology. Trends Ecol Evol 19:46-53.
172. Suding KN, Hobbs RJ. 2009. Threshold models in restoration and conservation: a developing framework. Trends Ecol Evol 24:271-9.

173. Texier D, de Noblet N, Braconnot P. 2000. Sensitivity of the African and Asian Monsoons to Mid-Holocene Insolation and Data-Inferred Surface Changes. J Clim 13:164-81.

174. Texier D, de Noblet N, Harrison SP, Haxeltine A, Jolly D, Joussaume S, Laarif F, Prentice IC, Tarasov P. 1997. Quantifying the role of biosphere-atmosphere feedbacks in climate change: coupled model simulations for 6000 years BP and comparison with palaeodata for northern Eurasia and northern Africa. Clim Dyn 13:865-81.

175. Thébault E, Huber V, Loreau M. 2007. Cascading extinctions and ecosystem functioning: contrasting effects of diversity depending on food web structure. Oikos 116:163-73.

176. Throop HL, Archer SR. 2007. Interrelationships among shrub encroachment, land management, and litter decomposition in a semidesert grassland. Ecol Appl 17:1809-23.

177. Trenberth KE. 1999. Atmospheric Moisture Recycling: Role of Advection and Local Evaporation. J Clim 12:1368-81.

178. Trisos CH, Merow C, Pigot AL. 2020. The projected timing of abrupt ecological disruption from climate change. Nature.

179. Trivedi C, Delgado-Baquerizo M, Hamonts K, Lai K, Reich PB, Singh BK. 2019. Losses in microbial functional diversity reduce the rate of key soil processes. Soil Biol Biochem 135:267-74.

180. Ulrich W, Soliveres S, Maestre FTFT, Gotelli NJNJ, Quero JLJL, Delgado-Baquerizo M, Bowker MAMA, Eldridge DJDJ, Ochoa V, Gozalo B, Valencia E, Berdugo M, Escolar C, García-Gómez M, Escudero A, Prina A, Alfonso G, Arredondo T, Bran D, Cabrera O, Cea AP, Chaieb M, Contreras J, Derak M, Espinosa CI, Florentino A, Gaitán J, Muro VG, Ghiloufi W, Gómez-González S, Gutiérrez JR, Hernández RM, Huber-Sannwald E, Jankju M, Mau RL, Hughes FM, Miriti M, Monerris J, Muchane M, Naseri K, Pucheta E, RamírezCollantes DA, Raveh E, Romão RL, Torres-Díaz C, Val J, Veiga JP, Wang D, Yuan X, Zaady E, others. 2014. Climate and soil attributes determine plant species turnover in global drylands. J Biogeogr 41:2307-19.

181. Verbesselt J, Umlauf N, Hirota M, Holmgren M, Van Nes EH, Herold M, Zeileis A, Scheffer M. 2016. Remotely sensed resilience of tropical forests. Nat Clim Chang 6:1028.

182. Villa Martín P, Bonachela JA, Levin SA, Muñoz MA. 2015. Eluding catastrophic shifts. Proc Natl Acad Sci 112:E1828 LP-E1836. 
183. Wang C, Wang X, Liu D, Wu H, Lü X, Fang Y, Cheng W, Luo W, Jiang P, Shi J, others. 2014. Aridity threshold in controlling ecosystem nitrogen cycling in arid and semi-arid grasslands. Nat Commun 5:4799.

184. Wang G, Eltahir EAB. 2000a. Biosphere -atmosphere interactions over West Africa. II: Multiple climate equilibria. Q J R Meteorol Soc 126:1261-80.

185. Wang G, Eltahir EAB. 2000b. Ecosystem dynamics and the Sahel Drought. Geophys Res Lett 27:795-8.

186. Wang H, Atkin OK, Keenan TF, Smith NG, Wright IJ, Bloomfield KJ, Kattge J, Reich PB, Prentice IC. 2020. Acclimation of leaf respiration consistent with optimal photosynthetic capacity. Glob Chang Biol 26:2573-83.

187. von Wehrden H, Hanspach J, Kaczensky P, Fischer J, Wesche K. 2012. Global assessment of the non-equilibrium concept in rangelands. Ecol Appl 22:393-9.

188. Wei F, Wang S, Fu B, Brandt M, Pan N, Wang C, Fensholt R. 2020. Nonlinear dynamics of fires in Africa over recent decades controlled by precipitation. Glob Chang Biol 26:4495-505.

189. Wendling V, Peugeot C, Mayor AG, Hiernaux P, Mougin E, Grippa M, Kergoat L, Walcker R, Galle S, Lebel T. 2019. Drought-induced regime shift and resilience of a Sahelian ecohydrosystem. Environ Res Lett 14:105005.

190. Wezel A, Rajot J-L, Herbrig C. 2000. Influence of shrubs on soil characteristics and their function in Sahelian agro-ecosystems in semi-arid Niger. J Arid Environ 44:383-98.

191. Wierzchos J, DiRuggiero J, Vítek P, Artieda O, Souza-Egipsy V, Škaloud P, Tisza M, Davila AF, Vílchez C, Garbayo I, Ascaso C. 2015. Adaptation strategies of endolithic chlorophototrophs to survive the hyperarid and extreme solar radiation environment of the Atacama Desert. Front Microbiol 6:934.

192. Van Wilgen BW, Govender N, Biggs HC, Ntsala D, Funda XN. 2004. Response of Savanna Fire Regimes to Changing Fire-Management Policies in a Large African National Park. Conserv Biol 18:1533-40.

193. Wright IJ, Reich PB, Westoby M, Ackerly DD, Baruch Z, Bongers F, Cavender-Bares J, Chapin T, Cornelissen JHC, Diemer M, Flexas J, Garnier E, Groom PK, Gulias J, Hikosaka K, Lamont BB, Lee T, Lee W, Lusk C, Midgley JJ, Navas M-L, Niinemets U, Oleksyn J, Osada N, Poorter H, Poot P, Prior L, Pyankov VI, Roumet C, Thomas SC, Tjoelker MG, Veneklaas EJ, Villar R. 2004. The worldwide leaf economics spectrum. Nature 428:821-7.
194. Xiaojun N, Jianhui Z, Zhengan S. 2013. Dynamics of soil organic carbon and microbial biomass carbon in relation to water erosion and tillage erosion. PLoS One 8:e64059-e64059.

195. Xiong D, Wei C, Wubs ERJ, Veen GF, Liang W, Wang X, Li Q, Van der Putten WH, Han X. 2019. Nonlinear responses of soil nematode community composition to increasing aridity. Glob Ecol Biogeogr 0.

196. Xu C, Hantson S, Holmgren M, van Nes EH, Staal A, Scheffer M. 2016. Remotely sensed canopy height reveals three pantropical ecosystem states. Ecology 97:2518-21.

197. Xu C, Nes EH Van, Holmgren M, Kéfi S, Scheffer M. 2015a. Local Facilitation May Cause Tipping Points on a Landscape Level Preceded by Early-Warning Indicators. Am Nat 186:E81-90.

198. Xu G, Tang S, Lu K, Li P, Li Z, Gao H, Zhao B. 2015b. Runoff and sediment yield under simulated rainfall on sand-covered slopes in a region subject to wind-water erosion. Environ Earth Sci 74:2523-30.

199. Xue Y. 2006. Interactions and feedbacks between climate and dryland vegetation. In: D'Odorico P, Porporato A, editors. Dryland Ecohydrology. Dordrecht: Springer Netherlands. pp 85-105.

200. Yao J, Liu H, Huang J, Gao Z, Wang G, Li D, Yu H, Chen X. 2020. Accelerated dryland expansion regulates future variability in dryland gross primary production. Nat Commun 11:1665.

201. Yosef G, Walko R, Avisar R, Tatarinov F, Rotenberg E, Yakir D. 2018. Large-scale semiarid afforestation can enhance precipitation and carbon sequestration potential. Sci Rep 8:996.

202. Yoshioka M, Mahowald N, Conley A, Fillmore D, Collins W, Zender C. 2005. Impact of Desert Dust Radiative Forcing on Sahel Precipitation. In: AGU Fall Meeting Abstracts. Vol. 2005. pp P13B-0157.

203. Zamani S, Mahmoodabadi M. 2013. Effect of particle-size distribution on wind erosion rate and soil erodibility. Arch Agron Soil Sci 59:1743-53.

204. Zeng N, Neelin JD. 2000. The Role of Vegetation-Climate Interaction and Interannual Variability in Shaping the African Savanna. J Clim 13:2665-70. 